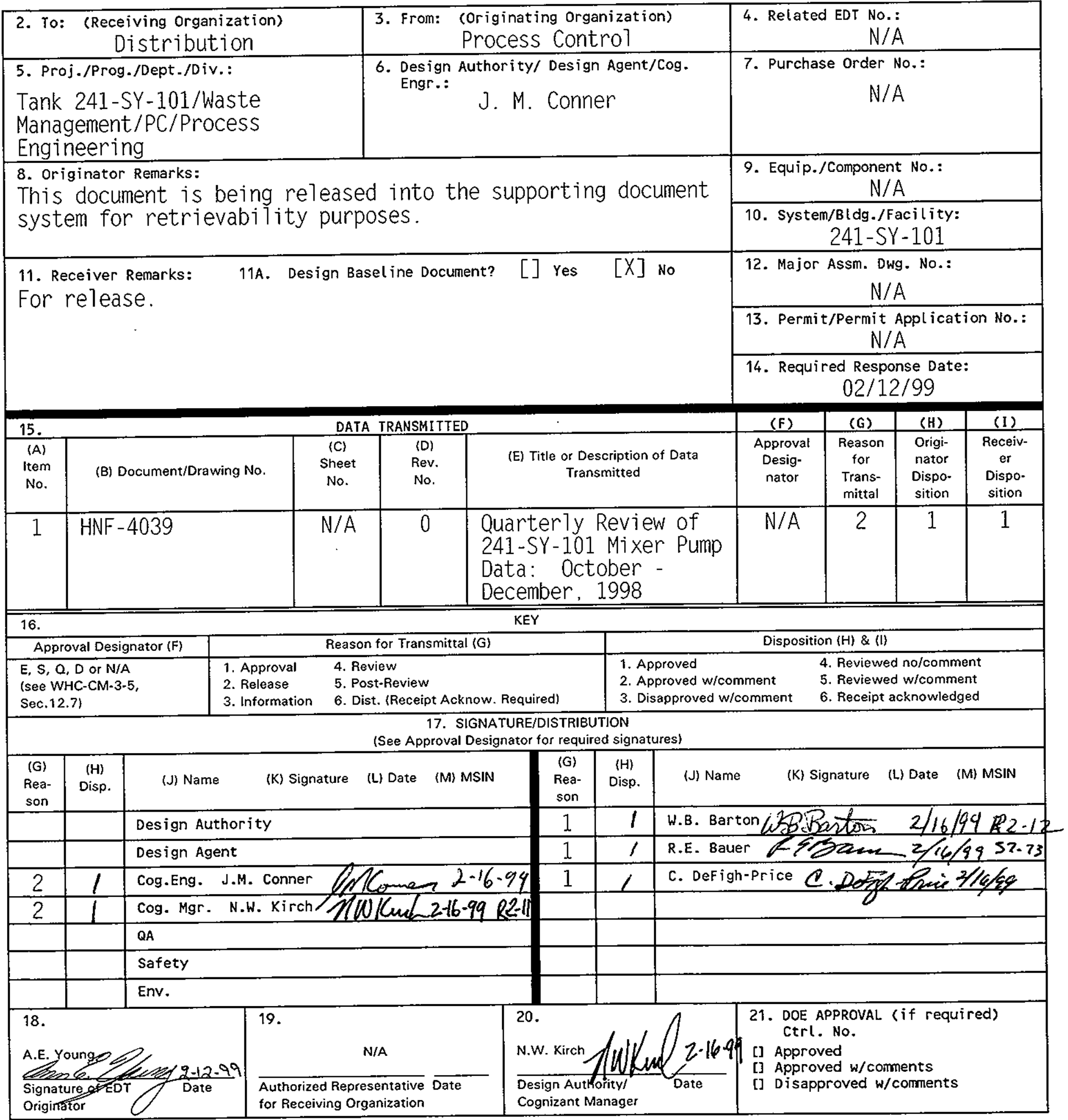

BD-7400-172-2 (05/96) GEF097 


\section{Quarterly Review of 241-SY-101 Mixer Pump Data: October - December, 1998}

J. M. Conner, G. M. Koreski

Lockheed Martin Hanford, Corp., Richland, WA 99352

EDT/ECN: EDT-611451 UC: 2070

Org Code: 7A150 CACN/COA: 101898/CB80

B\&R Code: EW 3120074 Total Pages: 42

Key Words: Tank 241-SY-101, Tank SY-101, SY-101, SY Farm, Quarterly Review, Mixer Pump Data, Mixer Pump

Abstract: N/A

Enraf is. a trademark of Enraf. Inc.

TRADEMARK DISCLAIMER. Reference herein to any specific comercial product, process, or service by trade name, trademark, manufacturer, or otherwise, does not necessarily constitute or imply its endorsement, recommendation, or favoring by the United States Government or any agency thereof or its contractors or subcontractors.

Printed in the United States of America. To obtain copies of this document, contact: Document Control Services, P.O. Box 950, Mailstop H6-08, Richland WA 99352, Phone (509) 372-2420;

Fax (509) 376-4989.
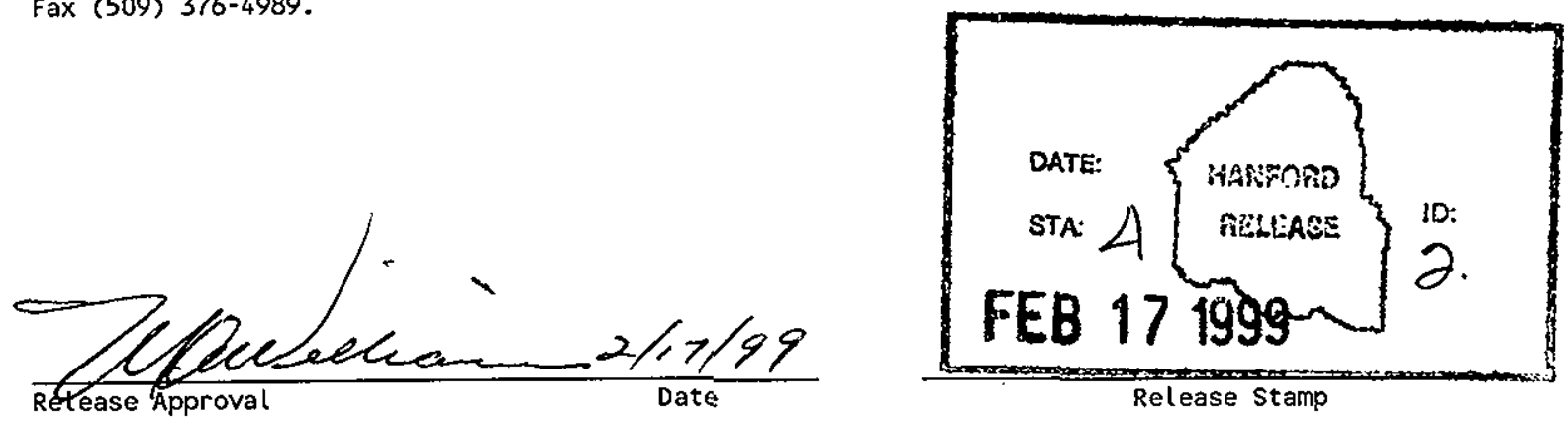

Approved for Public Release 
HNF-4039, Rev. 0

\subsection{QUARTERLY SUMMARY}

This report presents data obtained on 241-SY-101 pump performance. The period covered is October 1 through December 31, 1998.

During the quarter:

- There was an indication of a 7.0-inch increase in the waste level at riser $1 \mathrm{~A}$, and an average growth rate of 0.076 inches per day.

- There was an indication of a 2.3-inch increase in the waste level at riser 1C. This riser was flushed with water several times, which would lower the level of the crust at this location.

- Gases continued to be released at less than the pre-pump installation baseline rate, indicating a decrease in the gas generation rate, or an increase in gas retention, or both. The release rate was about 60 percent of the rate in the previous few quarters, and only 44 percent of the pre-pump release rate.

- There was no change in the parameters that monitor pump performance.

Key controls exist for waste temperature, gas concentration, pump parameters, and long-term waste behavior associated with the safe operation of the mixer pump that mitigates the buoyant displacement gas release event behavior of 241-SY-101. Table 1-1 compares the key controls and the current state of the waste as of December 31, 1998.

The pump was run 35 times between October 1 and December 31, 1998. Most of the pump runs were normal 25-minute, 1000-rpm excavation runs performed to mix the waste and release gas. Beginning in November, the pump oil high temperature alarm, set at $190^{\circ} \mathrm{F}$, would sometimes go off towards the end of pump runs. In those cases, the pump runs were shortened by approximately 1-2 minutes. The pump schedule was nominally three runs per week. However, core sampling activities interrupted the usual pump schedule several times during the quarter, resulting in less pump runs than normal. During this quarter, the pump showed no indication of degradation.

The Enraf level gauge in riser $1 \mathrm{~A}$ indicated a level increase of 7.0 inches. The estimated growth rate is 0.076 inches per day, which is much higher than the growth rate of 0.043 inches per day during the previous quarter. It appears that the level growth is due to gas being retained in or under the crust. A temperature validation probe at MIT $17 \mathrm{C}$ indicated that the crust is thickening and the level of settled solids may have increased slightly. The level growth phenomenon is discussed further in Section 7.0.

The gas chromatograph (GC) GC-3, was operational $94 \%$ of the time. GC-1 was operational $95 \%$ of the time. During the quarter, the calculated gas releases were $44 \%$ of the baseline generation rate prior to pump installation (and significantly less than last quarter). The final run of the quarter, on December 29,1998 , was the $1002^{\text {nd }}$ time the pump was operated since its installation in the tank. Hydrogen and nitrous oxide concentrations were lower than in previous quarters. 
HNF-4039, Rev. 0

Table 1-1. Key Controls

\begin{tabular}{|c|c|c|}
\hline Control & $\begin{array}{l}\text { Requirement for Normal } \\
\text { Pump Operation }\end{array}$ & Status as of $12 / 31 / 98$ \\
\hline Level & $\mathrm{N} / \mathrm{A}^{1}$ & $\begin{array}{l}\text { Riser } 1 \mathrm{~A}^{2}: 10.81 \mathrm{~m} \text { (425.7 in.) } \\
\text { Riser } 1 \mathrm{C}: 10.34 \mathrm{~m} \text { (407.3 in.) }\end{array}$ \\
\hline $\begin{array}{l}\text { Maximum Waste } \\
\text { Temperature }\end{array}$ & $<51.7^{\circ} \mathrm{C}\left(125^{\circ} \mathrm{F}\right)$ & $50.2^{\circ} \mathrm{C}\left(122.4^{\circ} \mathrm{F}\right)$ \\
\hline $\begin{array}{l}\text { Minimum Average } \\
\text { Waste Temperature }\end{array}$ & $>43.3^{\circ} \mathrm{C}\left(110^{\circ} \mathrm{F}\right)$ & $48.2^{\circ} \mathrm{C}\left(118.8^{\circ} \mathrm{F}\right)$ \\
\hline Hydrogen & $\begin{array}{l}\text { weekly average } \mathrm{H}_{2} \\
\text { concentration }>10 \text { ppm } \\
<7500 \text { ppm during pump } \\
\text { run }\end{array}$ & $\begin{array}{l}\text { weekly average } \mathrm{H}_{2} \text { concentrations } \\
\text { ranged from } 15 \text { to } 32 \mathrm{ppm} \\
<150 \text { ppm during pump runs }\end{array}$ \\
\hline $\begin{array}{l}\text { Long-Term Tank } \\
\text { Conditions }\end{array}$ & $\begin{array}{l}\text { any significant adverse } \\
\text { change }\end{array}$ & $\begin{array}{l}\text { level increase of } 0.076 \text { in. } / \mathrm{day}^{(3)} \text {; } \\
\text { level growth is being evaluated } \\
\text { (LMHC 1998) }\end{array}$ \\
\hline
\end{tabular}

${ }^{1}$ Level controls were removed by Standing Order TWO-99-001 (LMHC 1998). For tank intrusive operations, the standing order requires a review of level data to ensure a change of $>0.5$ inches has not occurred in the previous 24 hrs.

${ }^{2}$ See Appendix A for a discussion of riser numbering.

${ }^{3}$ Based on linear regression of the daily level at riser $1 \mathrm{~A}$. The level growth data from riser $1 \mathrm{C}$ were not used because $1 \mathrm{C}$ was subjected to several flushes.

\subsection{LEVEL}

The level at the end of the December quarter, according to the Enraf level gauge in riser $1 \mathrm{C}$, was $10.34 \mathrm{~m}$ (407.3 in.), indicated a level increase of 2.3 inches for the quarter. The other Enraf in riser $1 \mathrm{~A}$ indicated a level increase of 7.0 inches over the quarter. The level increases are discussed further in Section 6.0.

For the period from September 30 to December 31, 1998, the average difference (offset) between the two Enrafs was $42.2 \mathrm{~cm}$ (16.6 in.). This offset is 4.3 inches bigger than last quarter. The larger offset appears to be a result of flushes of the riser $1 \mathrm{C}$ level gauge. Figure 1 shows the Enraf-1C and Enraf-1A waste level measurements over the last year. Figure 2 shows the 1A level and the 120-day rolling average for the growth rate at riser 1A. The average growth rate has increased from about 0.020 at the beginning of 1998 to 0.076 at the end of 1998. 


\subsection{TEMPERATURES}

The mixed slurry layer had an average temperature of $48.2^{\circ} \mathrm{C}\left(118.8^{\circ} \mathrm{F}\right)$ on December 31, 1998, based on Data Acquisition and Control System (DACS) readings from MIT-17B. The mixed slurry layer average temperature was $48.4^{\circ} \mathrm{C}\left(119.1^{\circ} \mathrm{F}\right)$ on December 31, 1998, based on DACS readings from MIT-17C. These average waste temperatures are above the minimum control temperature of $43.3^{\circ} \mathrm{C}\left(110^{\circ} \mathrm{F}\right)$. The maximum temperature from the current temperature profile (DACS readings) is $50.2^{\circ} \mathrm{C}\left(122.4^{\circ} \mathrm{F}\right.$ ) which is below the maximum control temperature of $51.7^{\circ} \mathrm{C}\left(125^{\circ} \mathrm{F}\right)$. Figure 3 shows the vertical temperature profiles at MIT-17B and $-17 \mathrm{C}$ as of December 31, 1998.

Figure 4 shows the bulk average waste temperatures since January 1994. Temperatures at both MITs are following a seasonal trend, although the waste is approximately $1.5^{\circ} \mathrm{F}$ hotter than in previous years. In addition, it is not yet clear that the seasonal peak has been reached. Previously, the maximum temperature had been reached by the end of the December quarter. Possible reasons for the increased temperature are discussed in Section 7.

\subsection{GASES}

There were no unexpected large gas releases during the quarter. Gas continued to be released at less than the pre-pump installation baseline rate, consistent with past quarters. However, the rate of release is much lower than in previous quarters. The weekly average hydrogen concentrations have been above $10 \mathrm{ppm}$, although some weekly averages have approached this level. Table 4-1 lists this quarter's monthly average gas concentrations. Table 4-2 compares this quarter's average gas concentrations with past quarterly averages.

Hydrogen and nitrous oxide concentrations are lower than in previous quarters.

Table 4-1. Gas Monthly Average Concentrations

\begin{tabular}{||l|c|c|c||}
\hline \hline Gas (Instrument) & \multicolumn{3}{|c||}{ Monthly Average Concentrations (ppm) } \\
\hline \hline & $10 / 1 / 98-10 / 31 / 98$ & $11 / 1 / 98-11 / 30 / 98$ & $12 / 1 / 98-12 / 31 / 98$ \\
\hline Hydrogen (GC-1) & 24 & 20 & 18 \\
\hline Hydrogen (GC-3) & 21 & 23 & 23 \\
\hline Ammonia (FTIR) & 48 & 49 & 47 \\
\hline $\begin{array}{l}\text { Nitrous Oxide } \\
\text { (FTIR) }\end{array}$ & 17 & 19 & 19 \\
\hline
\end{tabular}


Table 4-2. Quarterly Average Concentrations

\begin{tabular}{|l|c|c|c|}
\hline Gas (Instrument) & $4 / 1 / 98-6 / 30 / 98$ & $7 / 1 / 98-9 / 30 / 98$ & $10 / 1 / 98-12 / 31 / 98$ \\
\hline Hydrogen (GC-1) & 31 & 39 & 21 \\
\hline Hydrogen (GC-3) & 31 & 33 & 22 \\
\hline $\begin{array}{l}\text { Ammonia (FTIR) } \\
\text { conc. varies seasonally) }\end{array}$ & 40 & 54 & 48 \\
\hline Nitrous Oxide (FTIR) & 27 & 24 & 18 \\
\hline
\end{tabular}

Figures 5, 6, and 7 show the hydrogen concentrations measured by GC-3 for each of the three months of this quarter. The hydrogen concentration in the dome reached as high as $188 \mathrm{ppm}$ during the pump run on December 20, 1998. Peaks in previous quarters have been higher - the peak one year ago was $350 \mathrm{ppm}$. Notable natural releases are indicated on October 1, November 15 and 20, and December 27.

Figures 8,9 , and 10 show the GC-1 measured hydrogen concentrations for October through December 1998. Based on this instrument, the hydrogen concentration in the dome reached as high as $229 \mathrm{ppm}$ during the pump run on October 19, 1998. Figures 11, 12, and 13 show the Fourier transform infrared spectrometer (FTIR) measured concentrations of ammonia and nitrous oxide for each month. High ammonia spikes on October 19 and December 23 are the result of ventilation shutdowns of 10 and 12 hours, respectively.

Figure 14 shows the calculated weekly total gas releases from January 1, 1994, to December 27, 1998. Daily total gas release volumes are calculated by integrating the product of the hydrogen concentration (GC-1) and the vent header flow rate and dividing by an assumed hydrogen fraction of 0.29 in the tank gas. These daily gas release volumes are summed on a weekly basis. Between October 4, 1998, and December 27, 1998, the average release was about $8.7 \mathrm{~m}^{3}\left(307 \mathrm{ft}^{3}\right)$ per week compared with the pre-pump installation baseline rate of $19.8 \mathrm{~m}^{3}\left(700 \mathrm{ft}^{3}\right)$ per week. A reduction in total gas release rate over time has been observed since the pump was installed in 1993 . The release rate for this quarter is only 57 percent of the previous quarter's calculated release rate.

An overall release rate can also be derived from estimates of gas generation and retention. The average generation/release rate prior to pump installation was $19.8 \mathrm{~m}^{3}\left(700 \mathrm{ft}^{3}\right)$ per week. The reduction in the generation rate can be calculated by assuming the key radionuclide in the waste is ${ }^{137} \mathrm{Cs}$. In the 5 years since the pump was installed, the ${ }^{137} \mathrm{Cs}$ concentration has dropped 11 percent because of radioactive decay. Assuming a linear relationship between the ${ }^{137} \mathrm{Cs}$ concentration and the gas generation rate, the current generation rate would be lower by $2.2 \mathrm{~m}^{3}\left(77 \mathrm{ft}^{3}\right)$ per week, or $17.6 \mathrm{~m}^{3}\left(623 \mathrm{ft}^{3}\right)$. The average level rise for the quarter $\left(0.076 \mathrm{in} /\right.$ day from ENRAF in riser 1A) corresponds to $5.5 \mathrm{~m}^{3}\left(196 \mathrm{ft}^{3}\right)$ of retained gas per week, assuming the gas is retained in the crust at nearly atmospheric pressure. Subtracting this retention estimate from the generation estimate $17.6 \mathrm{~m}^{3}\left(623 \mathrm{ft}^{3}\right)$ yields an estimated release rate of $12.1 \mathrm{~m}^{3}\left(427 \mathrm{ft}^{3}\right)$ per week. This calculation is somewhat higher than the $8.7 \mathrm{~m}^{3}\left(307 \mathrm{ft}^{3}\right)$ per week derived from the $\mathrm{H}_{2}$ release rate. Other than measurement 
errors, a possible reason for the discrepancy is that these calculations rely on assumptions for generation rates and $\mathrm{H}_{2}$ gas fractions that may no longer be valid.

Figure 15 shows the weekly volumes of ammonia and nitrous oxide released from January 1, 1994 to December 27, 1998. The seasonal variation of ammonia release is evident in the figure, although the latest upswing has been higher than the peak weekly values from previous years. A general decrease in nitrous oxide is also apparent. Figures 16, 17, and 18 show the weekly concentrations of hydrogen, nitrous oxide, and ammonia for the same period. The average $\mathrm{N}_{2} \mathrm{O} / \mathrm{H}_{2}$ ratio calculated from this quarter's weekly averages is 0.83 . Three years ago, from October to December 1995, the ratio was about 1.3.

\subsection{PUMP PARAMETERS}

The pump was run 35 times this quarter between October 1 and December 31, 1998. The schedule was typically three 25-minute, 1000-rpm excavation runs per week at the 12 standard orientations. Beginning in November, the pump oil high temperature alarm, set at $190^{\circ} \mathrm{F}$, would sometimes go off towards the end of pump runs. In those cases, the pump runs were shortened by approximately 1-2 minutes. Core sampling activities restricted the pumping schedule several times because of the restriction that the pump not be run with the drill string in the waste. There were several stretches of approximately 1 week where the pump was not run. The runs on October 16 and 17 were not complete 25 -minute runs due to equipment problems.

Mixer pump performance remained unchanged during the quarter. Monitoring of the current, voltage, motor speed, volute and nozzle pressures, and oil temperature rate of rise indicated no degradation in performance. The current, voltage, and motor speed relationships have remained constant, as have the volute and nozzle pressures. There has been no indication of moisture in the motor oil. A sensor is located in the pump sump specifically for detecting water in the motor oil.

Data for a typical run during this quarter, on December 28,1998 , are presented in Figures 19-25. Figures 19 and 20 show nozzle pressures on a coarse and fine scale. Figure 21 shows volute pressure; Figure 22 shows pump current, voltage, and speed on a coarse scale; and Figures 23, 24, and 25 show the same data on a finer scale. Figure 26 shows the motor oil heat-up during the run. There were no significant changes in the values of these parameters during the quarter.

Although the oil temperature rise during pump runs has remained consistent, the oil cooling rate was identified as an issue in late December. The oil cooling rate is much slower than it was just a few months ago (Figure 27). The most likely explanations for the different cooling rate are that the bulk waste temperature is higher, leading to reduced heat transfer, or that a small hole in the top of the pump housing which previously allowed the hot waste around the pump to convect away, has become plugged. This issue is being evaluated.

The annual mixer pump motor winding insulation resistance check was completed December 29, 1998. All measured resistances were satisfactory (Gauck 1999). 
HNF-4039, Rev. 0

\subsection{CORE SAMPLING ACTIVITIES}

Core sampling activities were initiated in accordance with Conner (1998). One of the three full depth, push mode core samples had been taken by the end of December. Laboratory results will be referenced in a future quarterly report.

\subsection{WASTE BEHAVIOR}

As discussed in Section 2.0, the Enraf level gauge in riser 1A showed an increase of 7.0 inches during the quarter. This gauge showed approximately 3.5 -inch increases in the two previous quarters, and a two-inch increase during the two quarters before that. Prior to one year ago, the level only increased about an inch per quarter. The growth rate at riser $1 \mathrm{~A}$ was 0.076 in. per day based on a linear regression of the daily level data. This rate is about the same as the pre-pump baseline growth rate ( 0.08 in. per day).

A very slight, adverse trend towards build-up of nonconvective solids appears to be occurring. Figure 28 shows the bottom four thermocouples of MIT-17B during the pump run on December 10, when a nozzle was pointed in the direction of this MIT (97 degrees). All of the thermocouples responded, although the bottom thermocouple did not quite reach the bulk temperature. This indicates an undisturbed layer of slightly greater than 4 inches thick at a distance of $8.60-\mathrm{m}(28.2 \mathrm{ft})$ from the pump at this location. This is the first time since 1994 that the bottom thermocouple at MIT 17B did not reach the bulk slurry temperature during a pump run at this angle.

Figure 29 shows the MIT-17C bottom four thermocouples during the pump run of December 1 , when a nozzle was pointed in the direction of the MIT (28 degrees). The data indicate an undisturbed solids layer somewhat higher than 16 inches. The thermocouple at the 16-inch level responds, but does not reach the bulk slurry temperature. The MIT is $9.32 \mathrm{~m}$ (30.6) feet from the pump, or 2.4 feet further than MIT 17B. Pump runs at this angle have occasionally excavated solids down to the 16-inch level, but not in the last year or so. The pump seems to be slightly less effective at excavating the settled solids at the MITs. This behavior is being monitored closely.

According to the MIT validation probe temperature profiles, an increase in crust thickness is occurring. The crust is approximately $2.5 \mathrm{~m}$ (100 in) thick based on the latest validation probe in MIT 17C (Figure 30). The crust thickness was reportedly $1 \mathrm{~m}$ (40 in.) thick in 1993 and for several years thereafter, and was estimated at $1.6 \mathrm{~m}$ (63 in) last quarter. Since the estimates from the last two quarters are from different risers, the sudden change may be at least partly due to variations in the crust topography and thickness. Figure 30 also shows the validation probe from October 24,1996 in MIT 17C. The major differences between that probe and the December 8 probe are that the crust is now thicker, the settled solids layer appears thicker, and the waste is generally hotter by about $1.5^{\circ} \mathrm{F}$. The increase in temperature may be due to the thicker crust providing more insulation, limiting heat loss to the dome space.

The gas volumes calculated from the VFI data (Stewart et al. 1998), combined with a hydrostatics model for crust buoyancy, accurately reflected the waste level changes from 
January 1995 to July 1998 . This confirms that the SY-101 level growth is mainly due to gas accumulation in the crust (Stewart et al. 1998). A large buoyant displacement is not credible given the current configuration of the waste. The settled solids layer in the tank no longer stores enough gas to cause a large rollover.

In summary, many changes have been observed in the tank recently. The level growth issue was identified to be a significant problem approximately a year ago. The growth rate has accelerated to a current level of 0.076 inches per day, near the level growth rate prior to mixer pump installation. The level growth has been attributed to an increase in the amount of gas stored in the crust. The bulk slurry appears to be relatively free of gas voids. The crust thickness has increased significantly. The settled solids may have increased slightly and are not as readily excavated by the pump. The hydrogen dome concentration and release rates have dropped recently, as has the peak hydrogen concentrations following pump runs. This is consistent with a thicker crust (providing more resistance to gas migration). The nitrous oxide concentrations and release rates have been trending downward for at least two years. Finally, the bulk waste temperature is hotter than it has been for at least 4 years. The Test Review Group (TRG) will continue to monitor the tank parameters and determine what changes (if any) to pump operations should occur.

\subsection{OTHER PARAMETERS}

There were no unexpected changes in the other tank parameters that were monitored for changes in waste behavior. Figure 31 shows the tank pressure and vent header flow rate histories. The pressure and flow rate were normal for the quarter. Ventilation shutdowns occurred on October 19, November 6, and December 23. Figure 32 shows the vent header and atmospheric relative humidity histories. The water balance between ambient and vent header humidity indicates that during the quarter the waste gained about 2.0 gallons of water per day. Figure 33 shows the vent header and atmospheric temperatures during the quarter.

\section{REFERENCES}

Conner, J. M., 1998, Push Mode Core Sampling and Analysis Plan for Double-Shell Tank 241-SY-101, HNF-3375, Rev. 0, Lockheed Martin Hanford Corporation, Richland, Washington.

Gauck, G. J., 1999, Data From Mixer Pump Windings Test, HNF-3900, Lockheed Martin Hanford Corporation, Richland, Washington.

LMHC, 1998, Waste Surface Level Change in Tank 241-SY-101, Unreviewed Safety Question TF-97-0975, Rev. 2, Lockheed Martin Hanford Corporation, Richland, Washington.

Stewart, C. W., J. M. Alzheimer, G. Chen, and P. A. Meyer, 1998, In Situ Void Fraction and Gas Volume in Hanford Tank 241-SY-101 as Measured with the Void Fraction Instrument, PNNL-12033, Pacific Northwest National Laboratory, Richland, Washington. 
HNF-4039, Rev. 0

\section{APPENDIX A}

\section{RISER NUMBERING}

This document continues to use the historical riser numbers assigned when the tank was designed. A drawing was recently released (H-14-010531) which changed the riser numbering of tank 241-SY-101. The table below lists the old and new riser numbers for risers that are used for monitoring or sampling.

\begin{tabular}{|c|c|c|}
\hline Old Riser Number & New Riser Number & A \\
\hline $1 \mathrm{C}$ & 001 & Enraf \\
\hline $1 \mathrm{~A}$ & 002 & Enraf \\
\hline $4 \mathrm{~A}$ & 006 & Spare \\
\hline $11 \mathrm{~B}$ & 011 & Spare \\
\hline $11 \mathrm{~A}$ & 012 & Spare \\
\hline $17 \mathrm{~B}$ & 018 & MIT \\
\hline $17 \mathrm{C}$ & 019 & MIT \\
\hline $22 \mathrm{~A}$ & 021 & Gas Monitoring \\
\hline $23 \mathrm{~A}$ & 022 & Spare \\
\hline
\end{tabular}




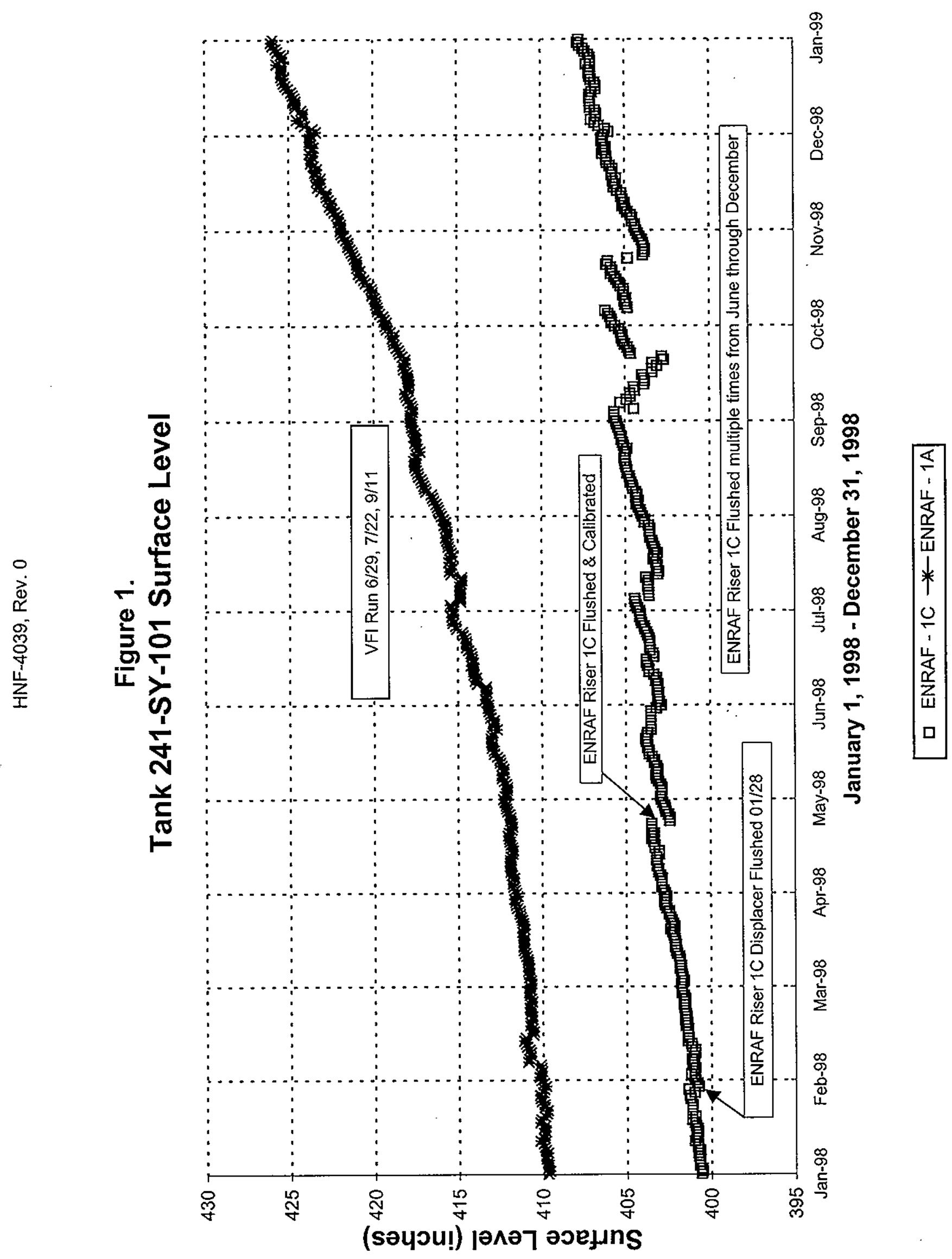

0
0
$\square$
$\square$
$\square$ 


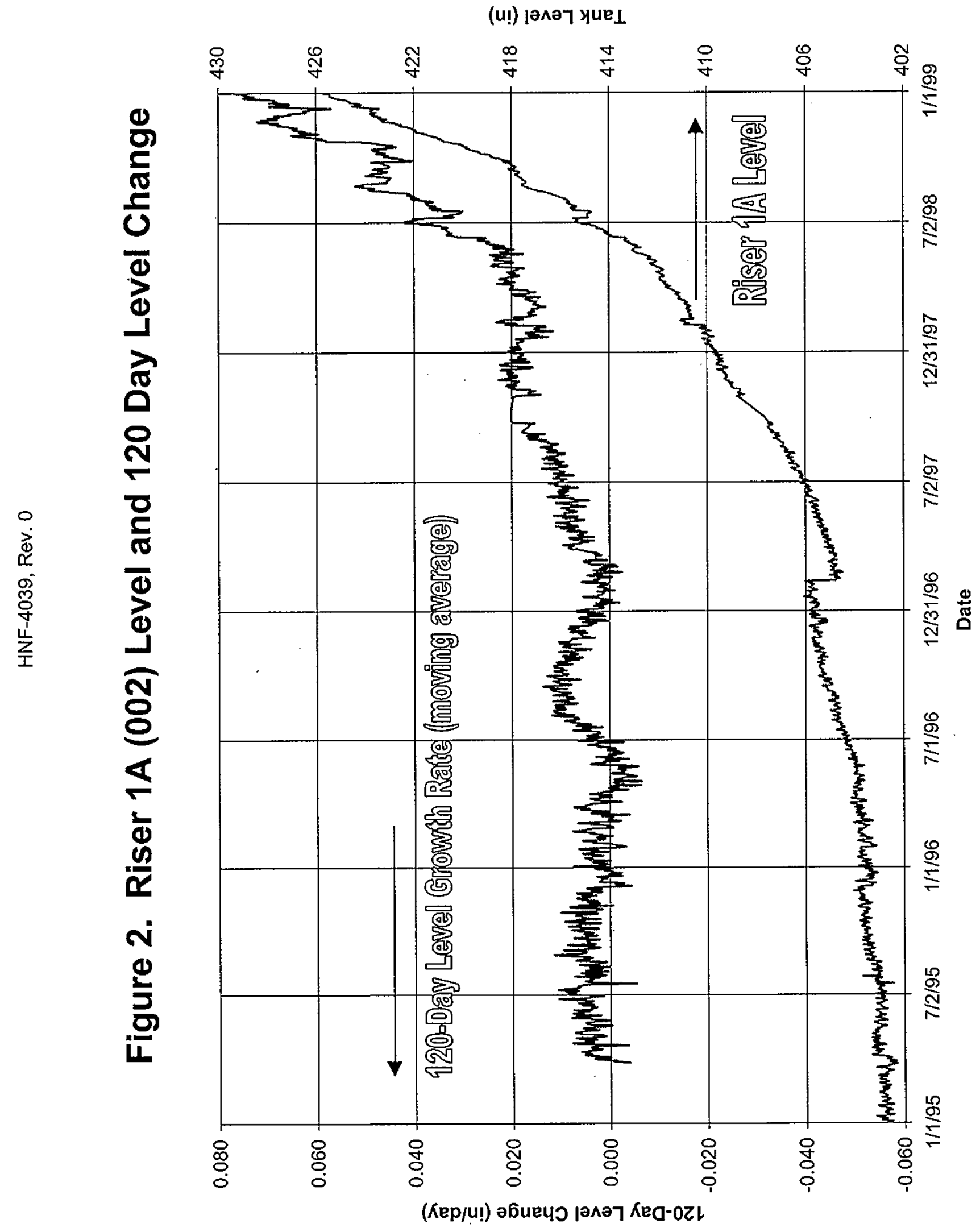

$\frac{0}{0}$
$\frac{0}{\pi}$
2 


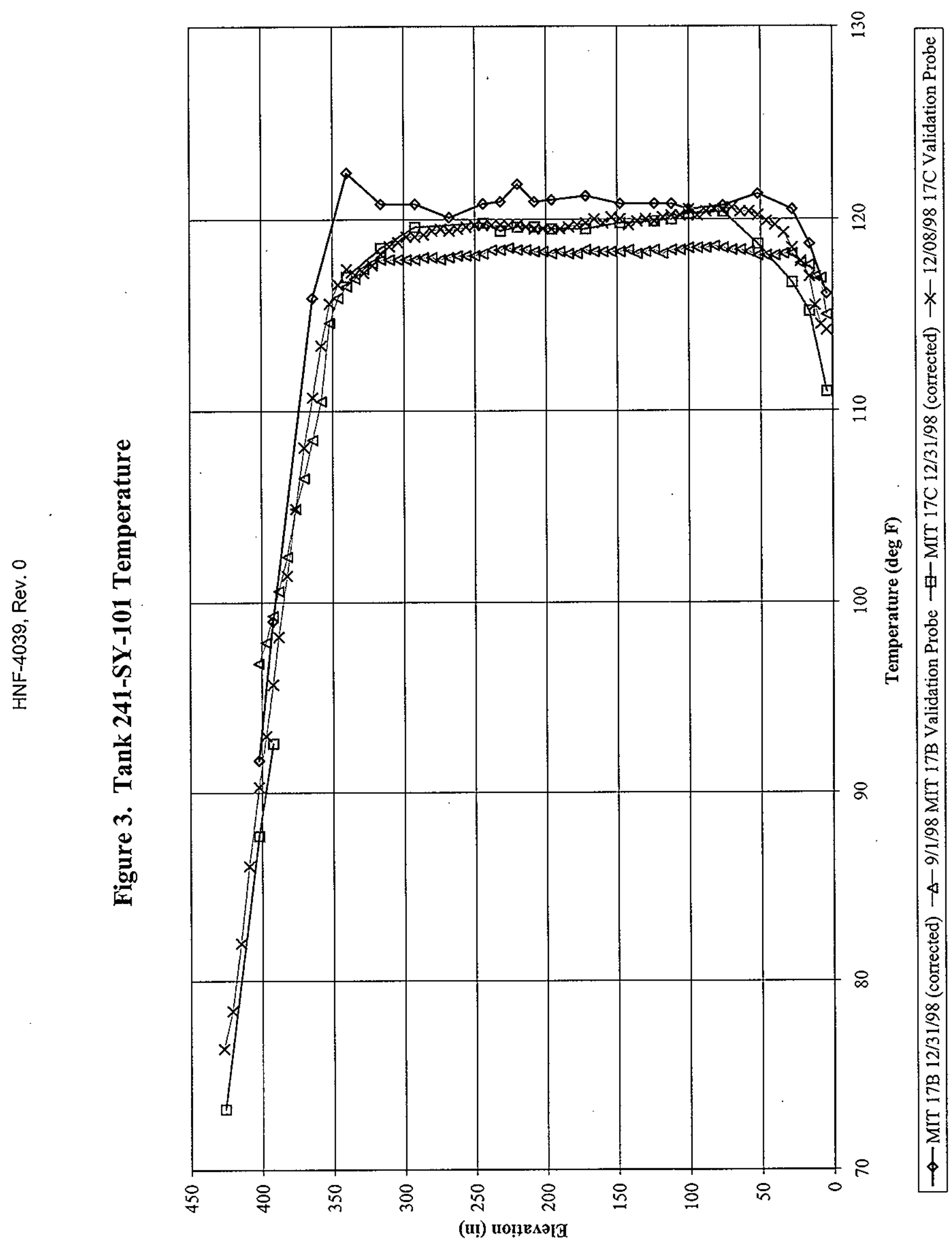




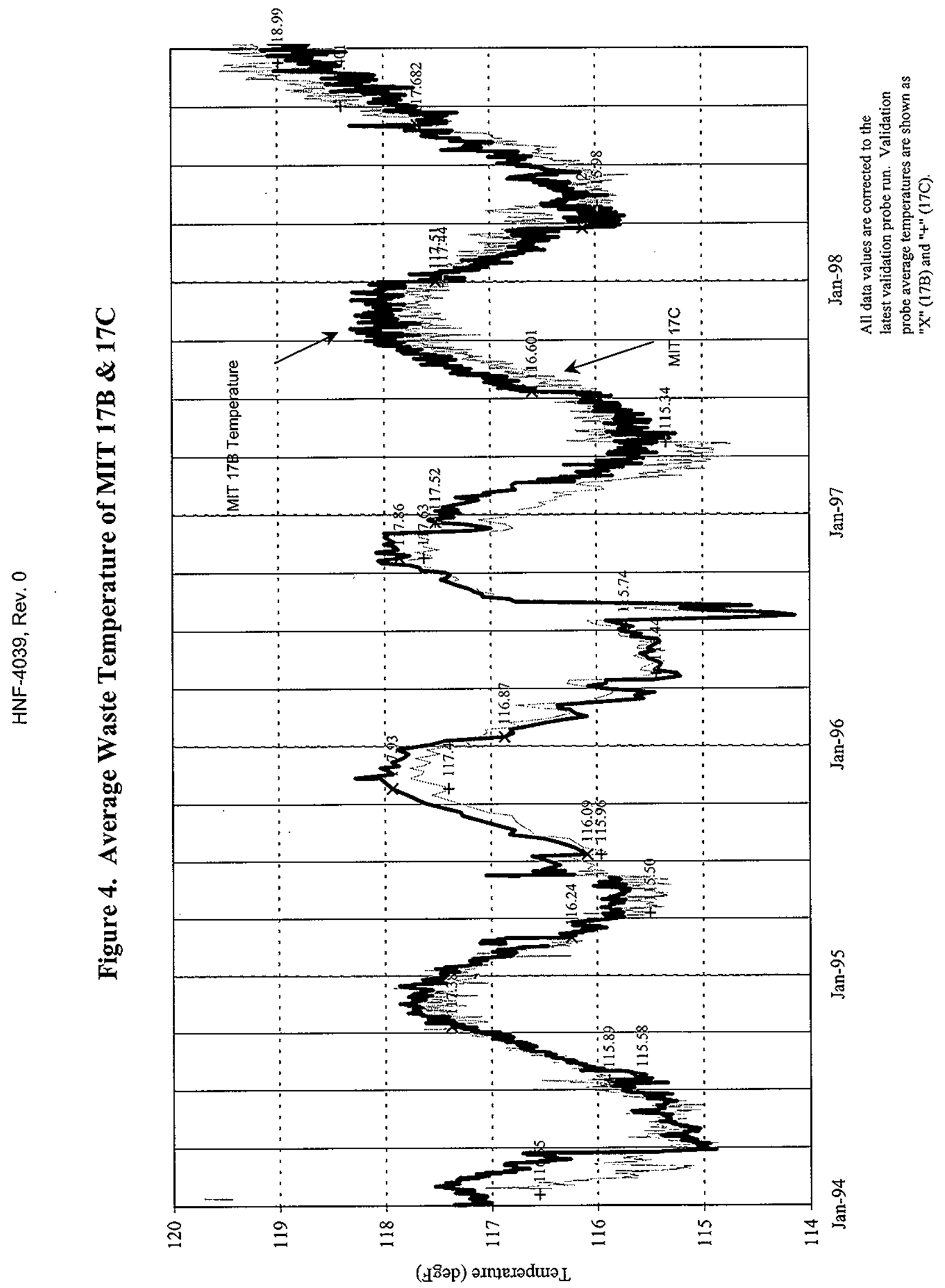

$\frac{N}{\infty}$ 


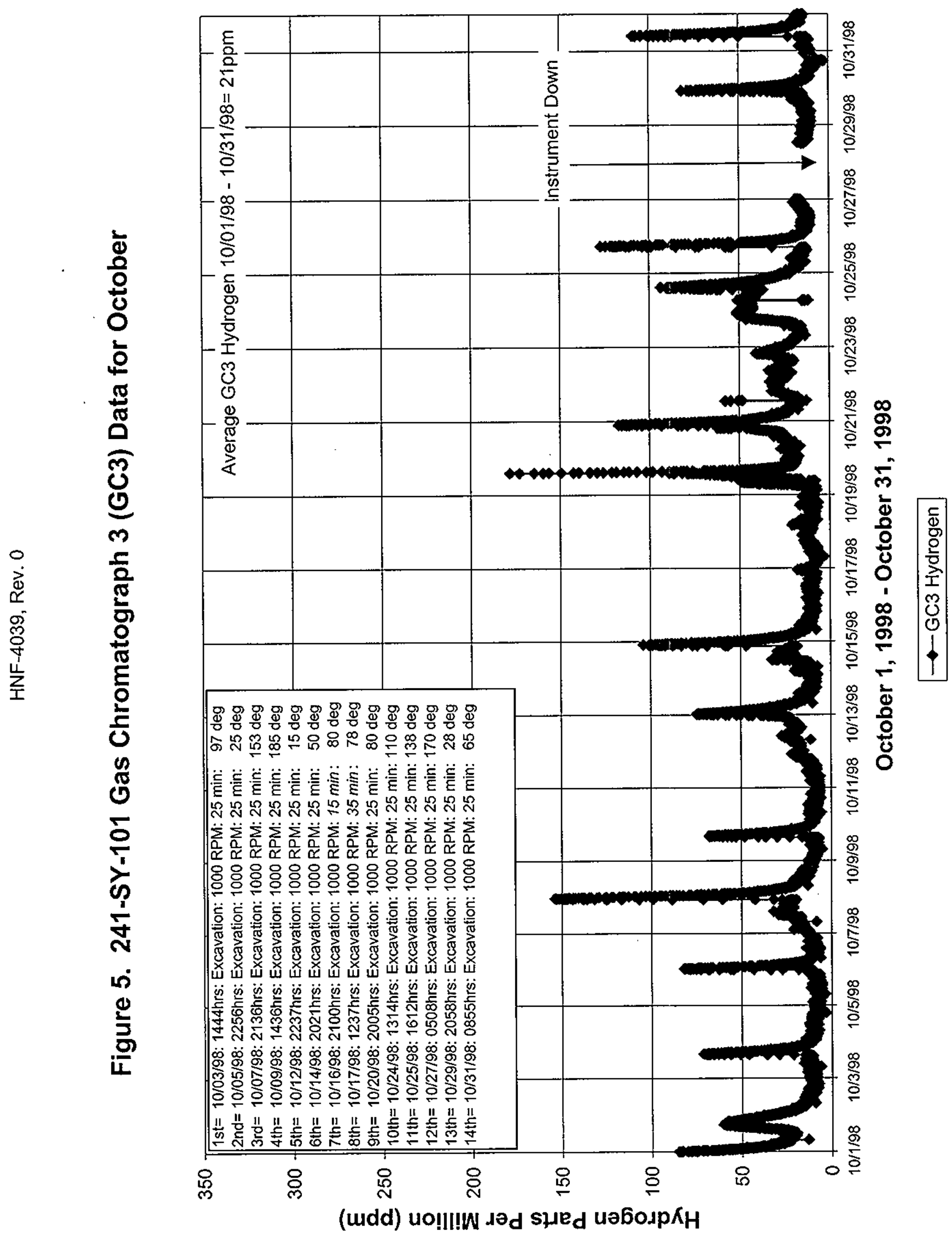

$\frac{m}{0}$ 


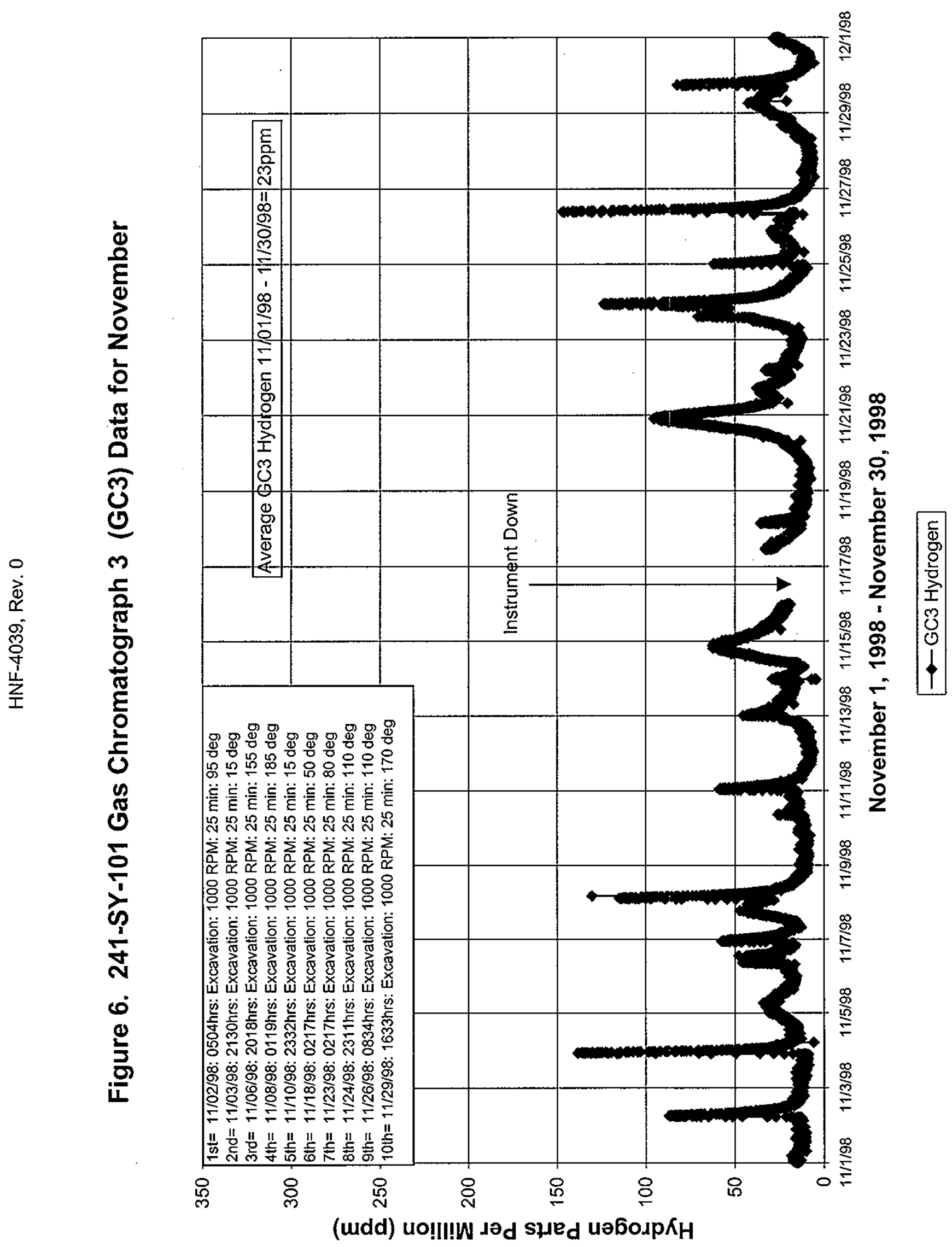

\pm
$\stackrel{8}{8}$
0 


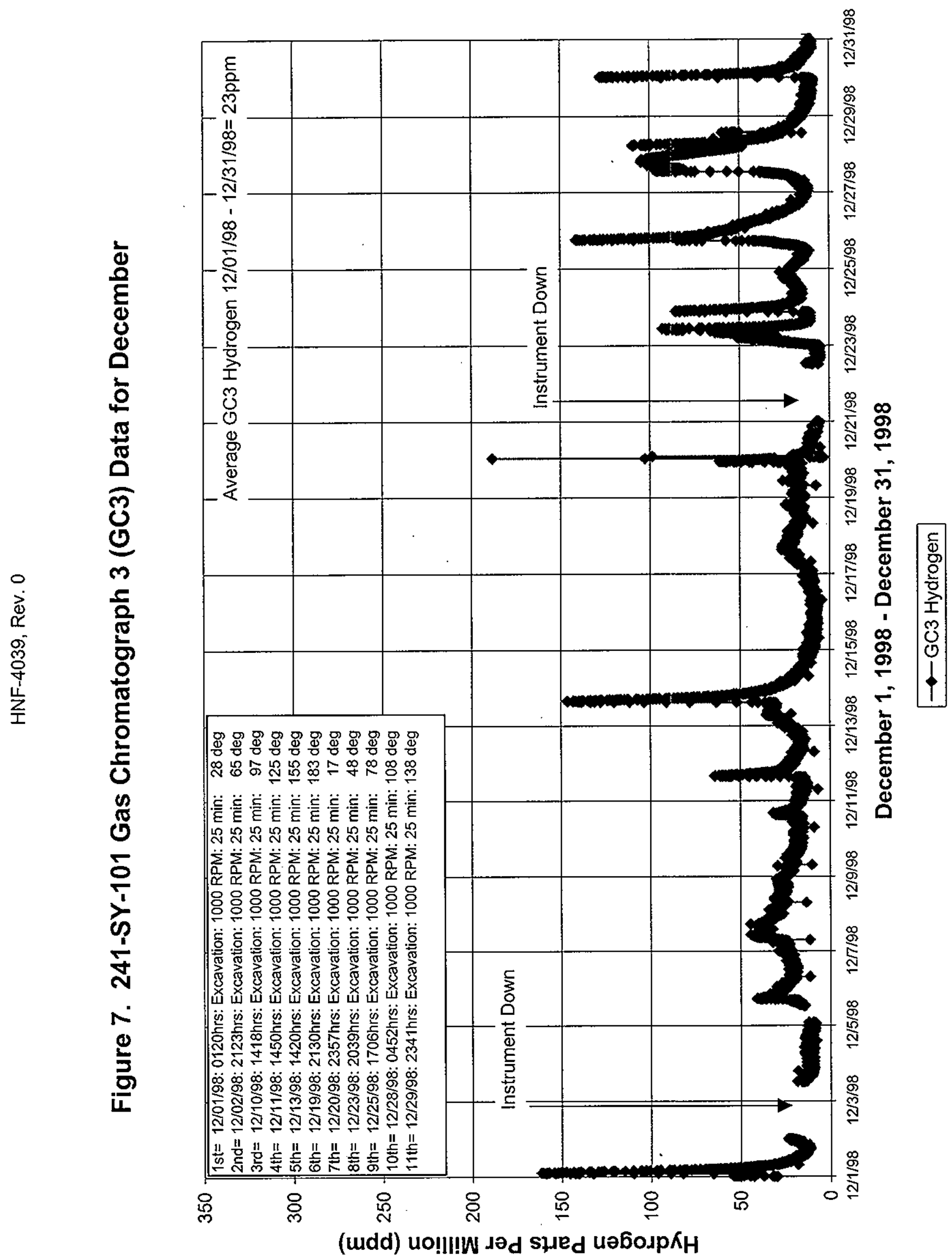

$\frac{10}{0}$
$\stackrel{0}{0}$
0 


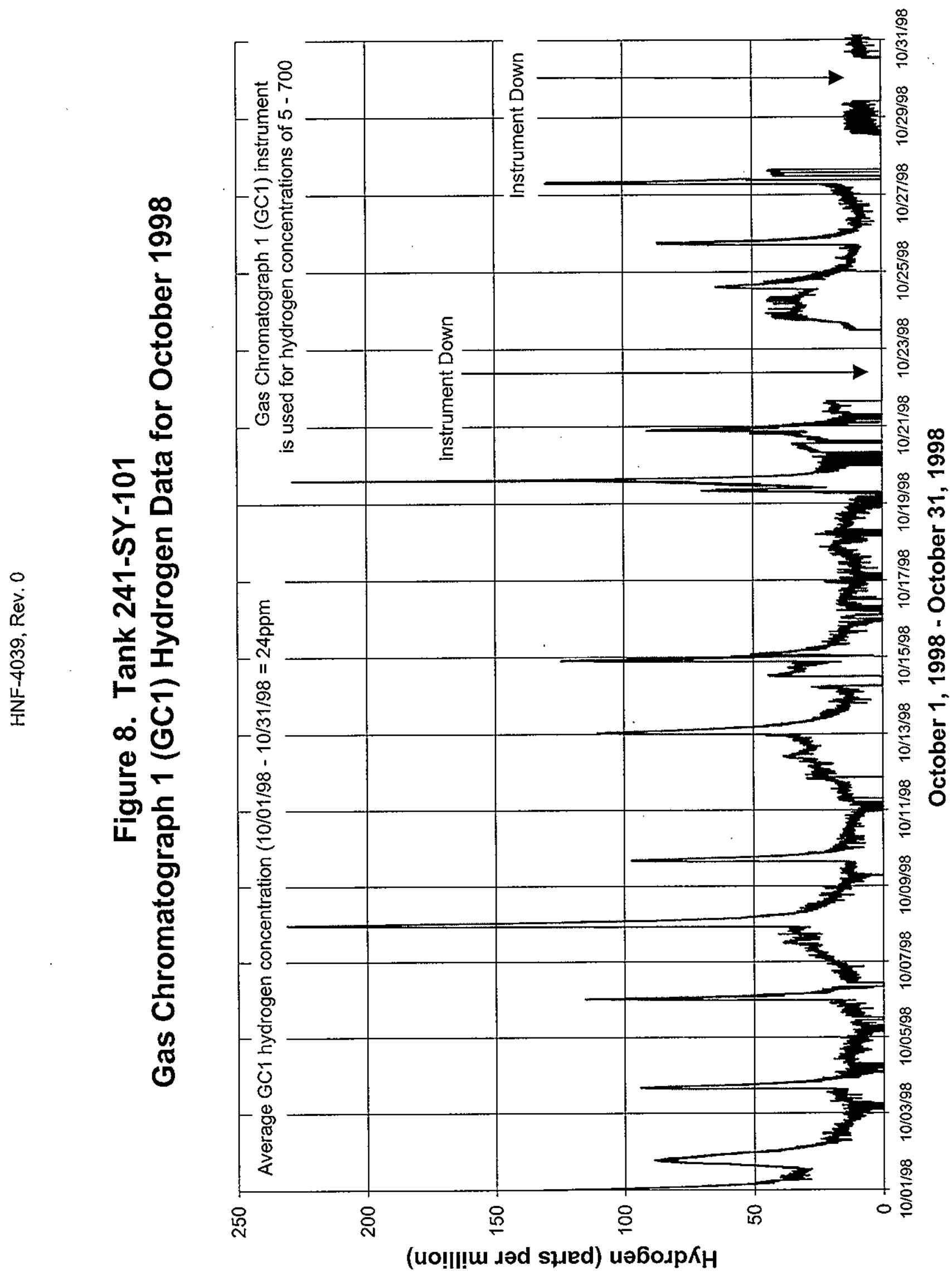

$\frac{6}{6}$
0
0
0 


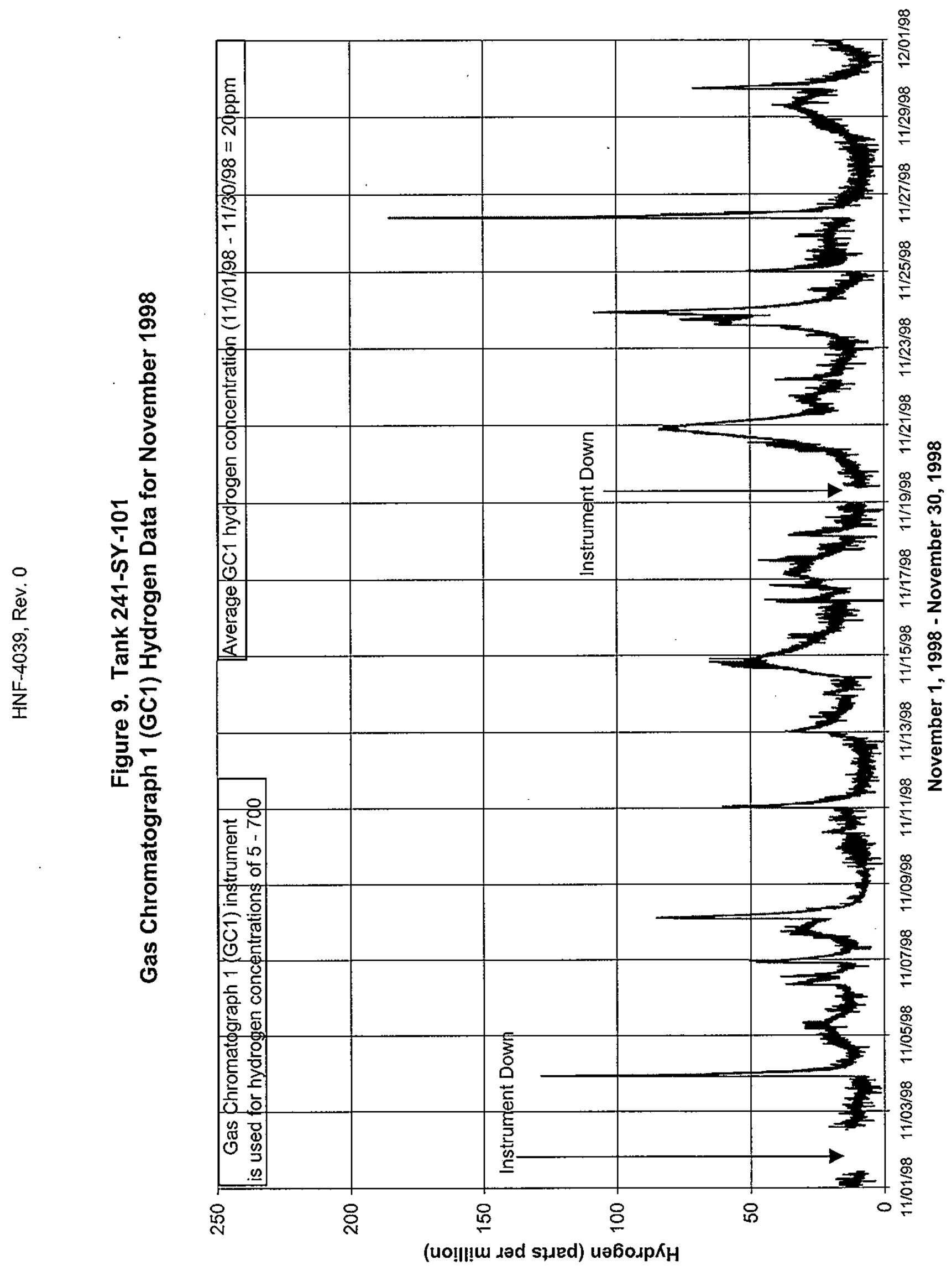

\begin{tabular}{l}
\multirow{0}{0}{} \\
$\frac{0}{0}$ \\
0
\end{tabular} 


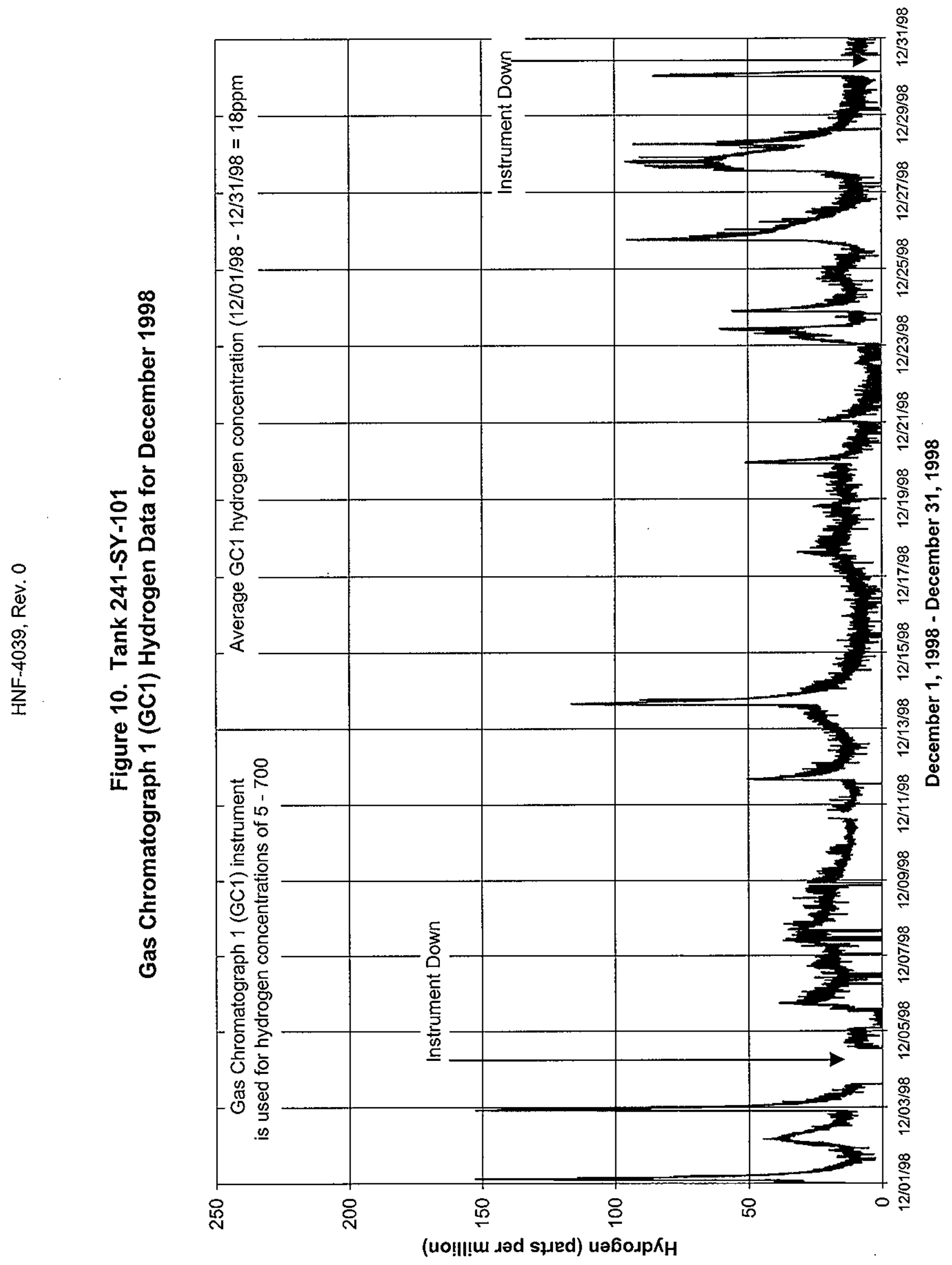

$\frac{\infty}{0}$
$\stackrel{0}{\sigma}$
0 


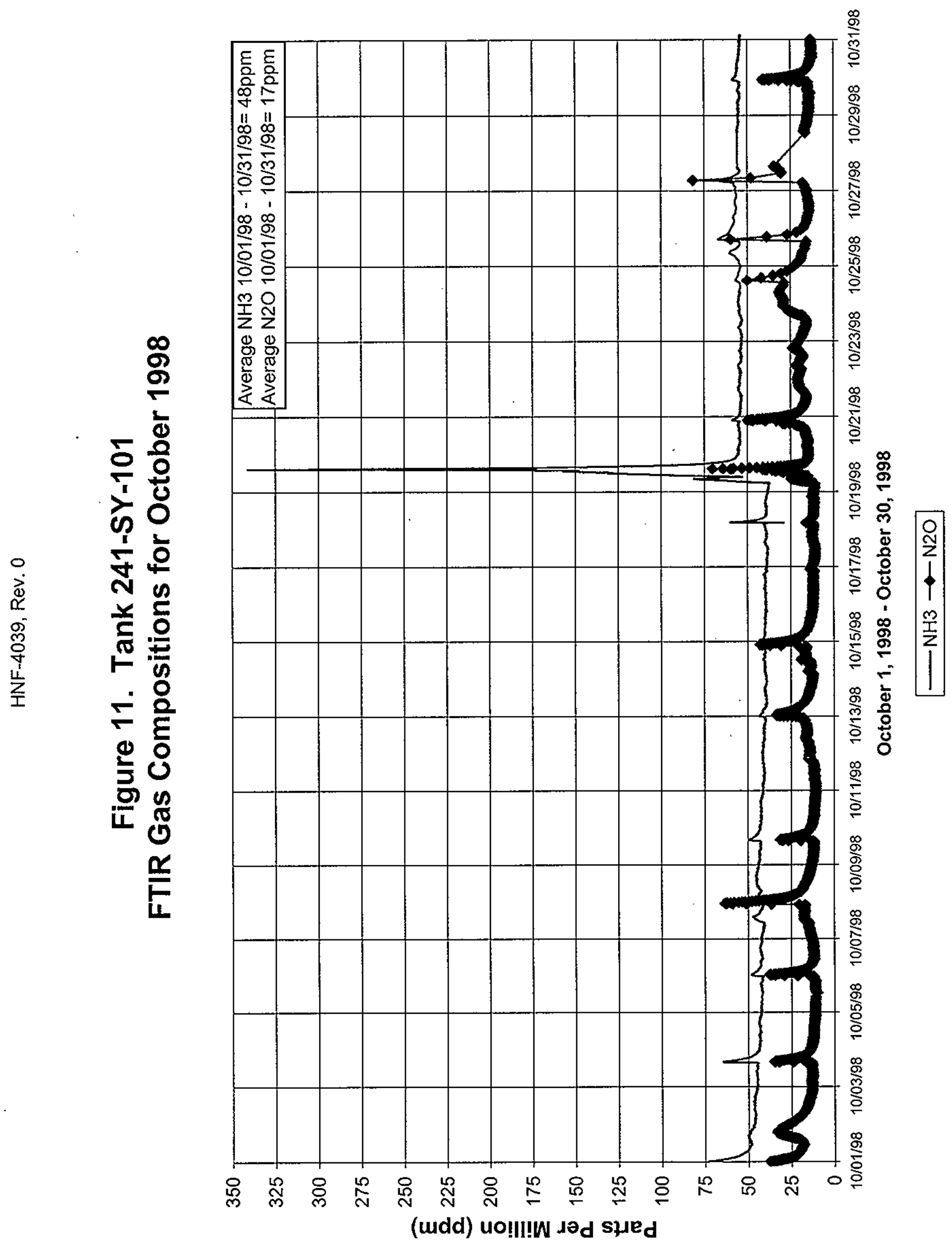

$\frac{0}{0}$
8
0
0 


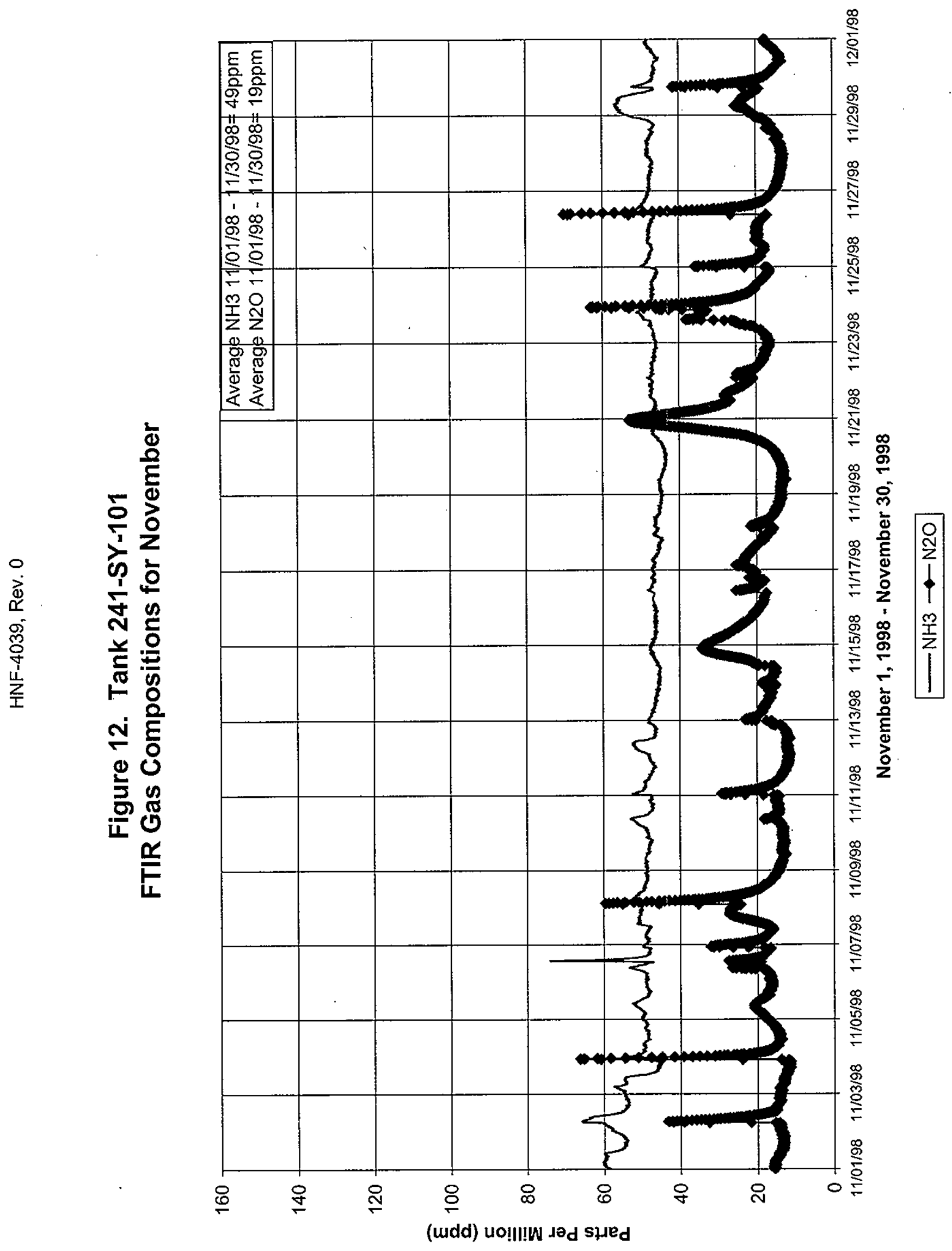




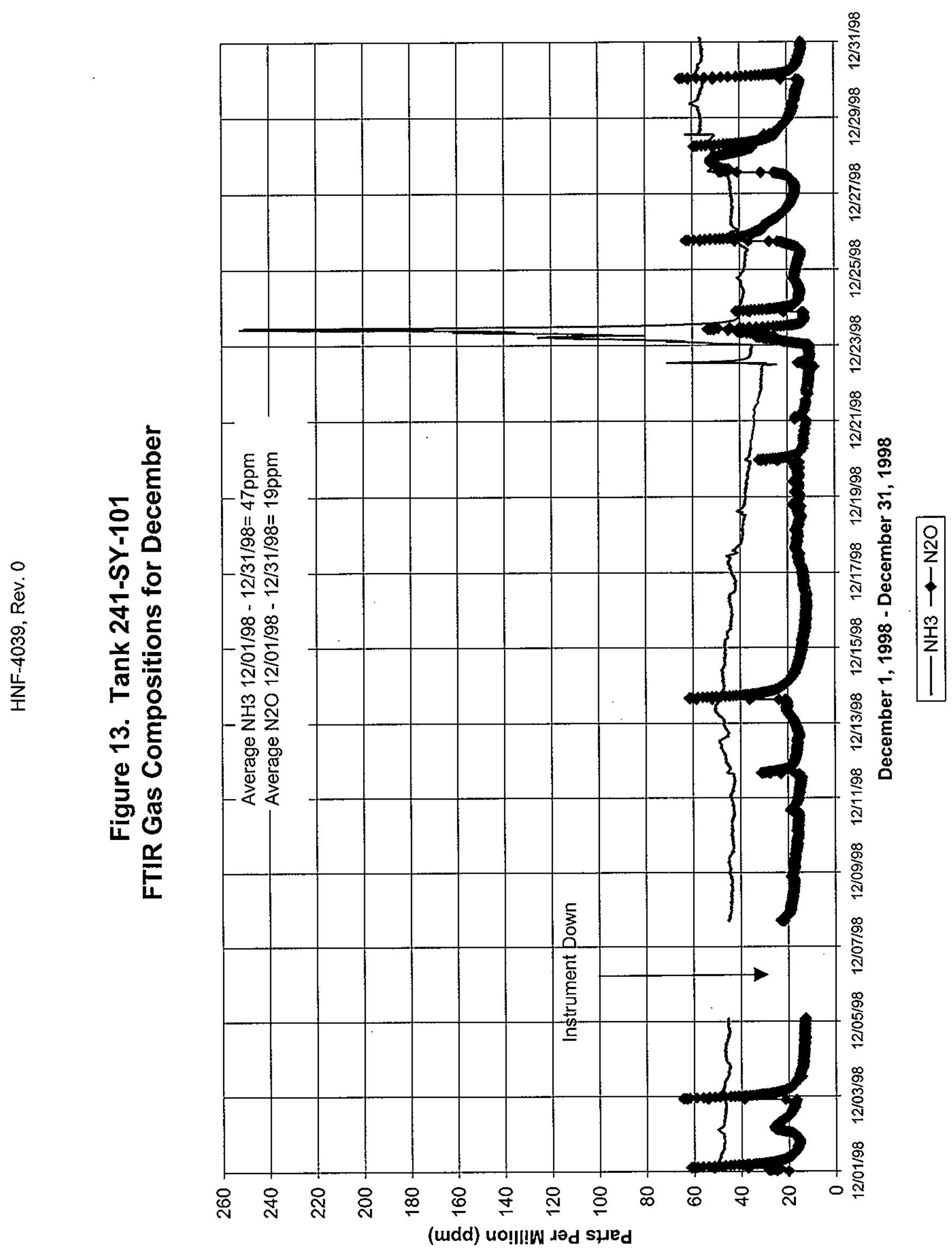

$\overleftarrow{N}$
$\mathbb{D}$
$\mathbb{N}$
0 

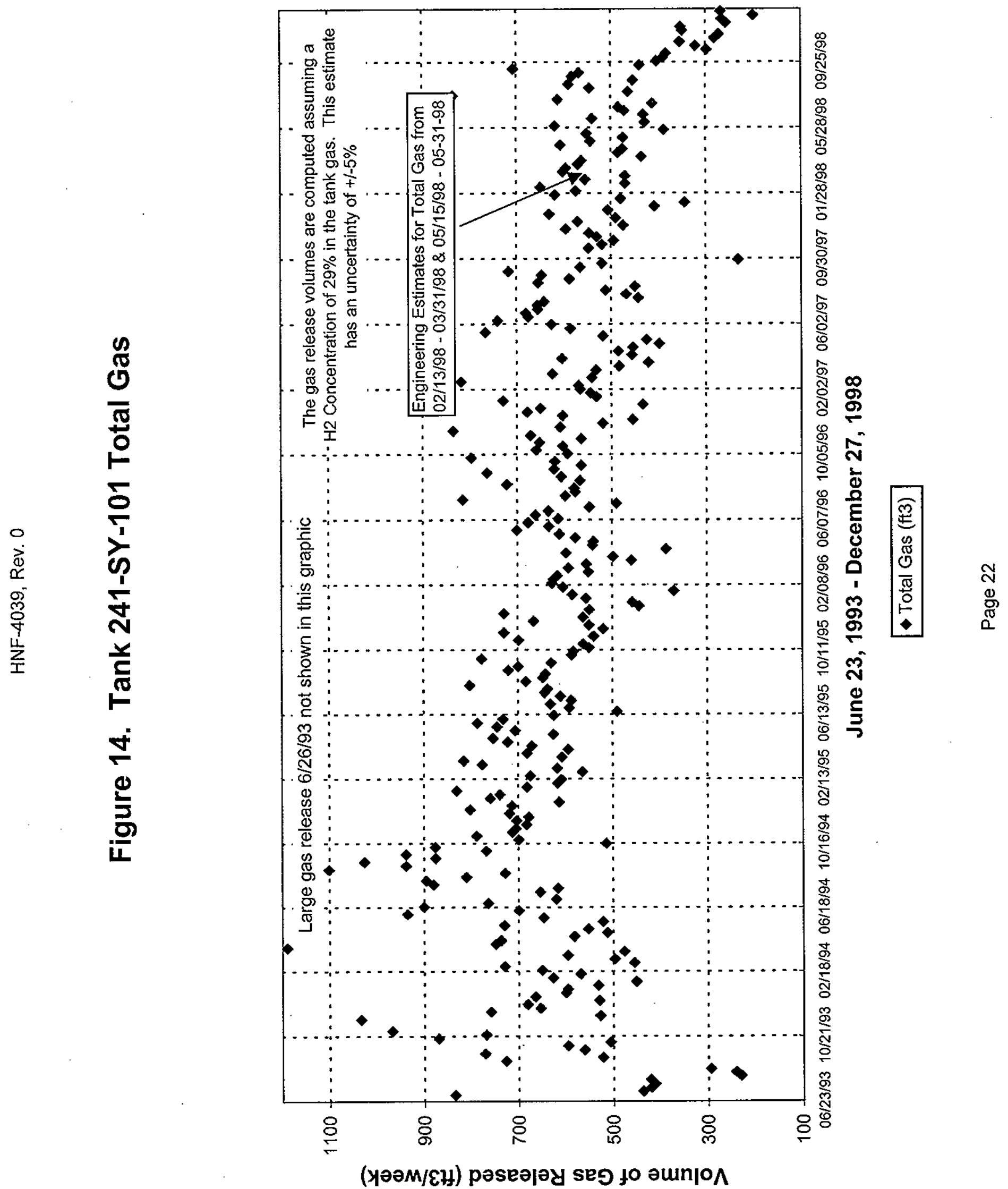


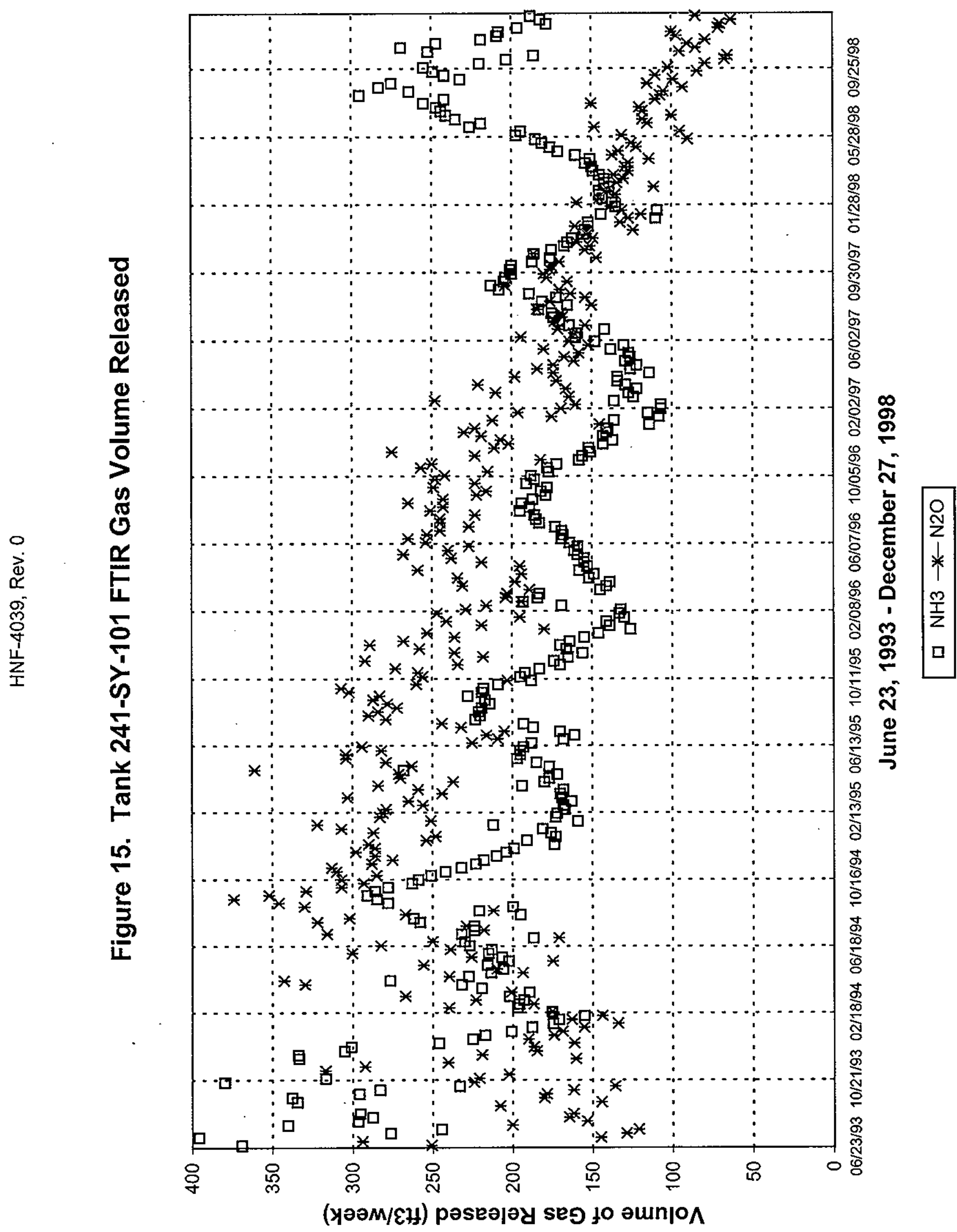

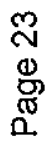




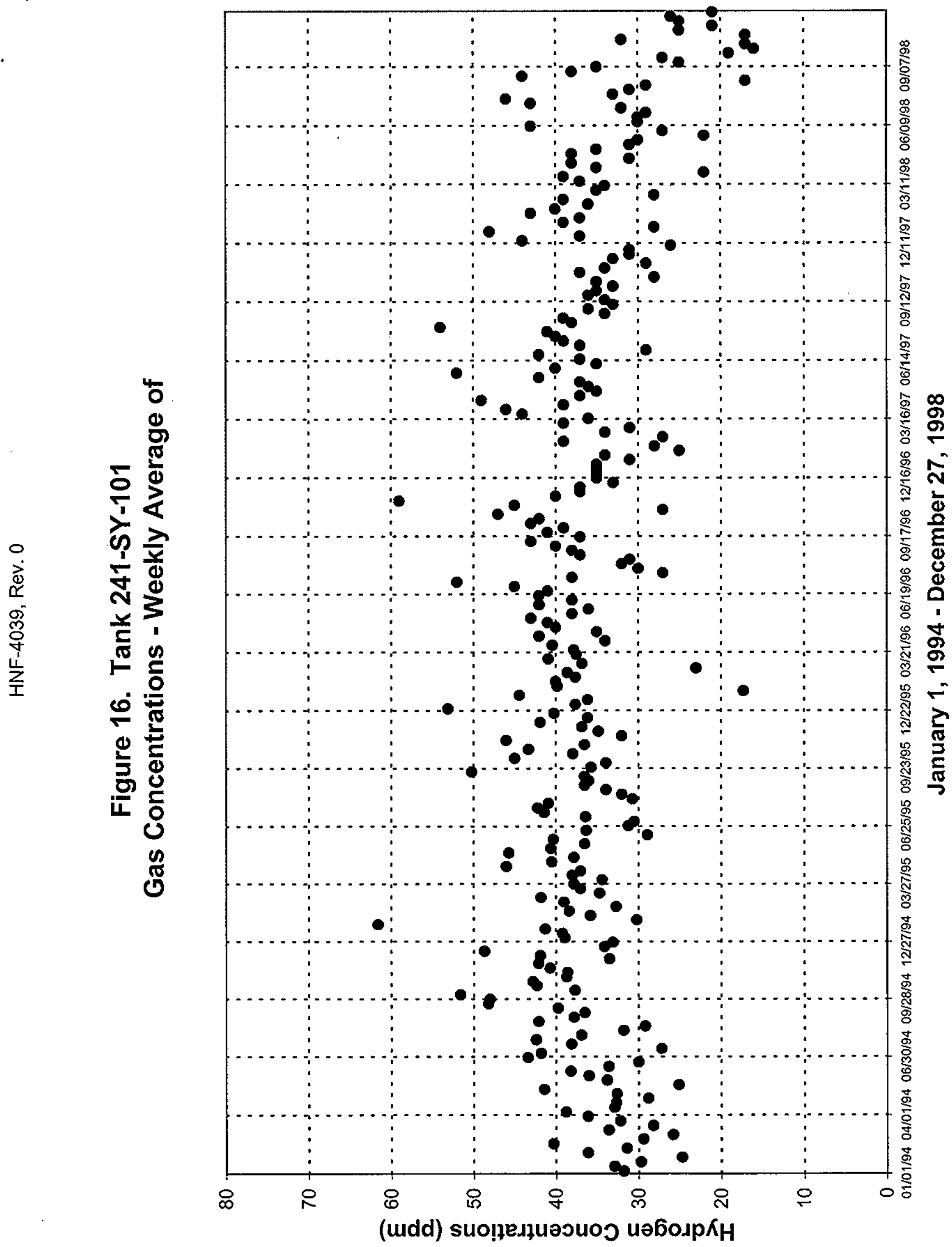

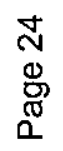




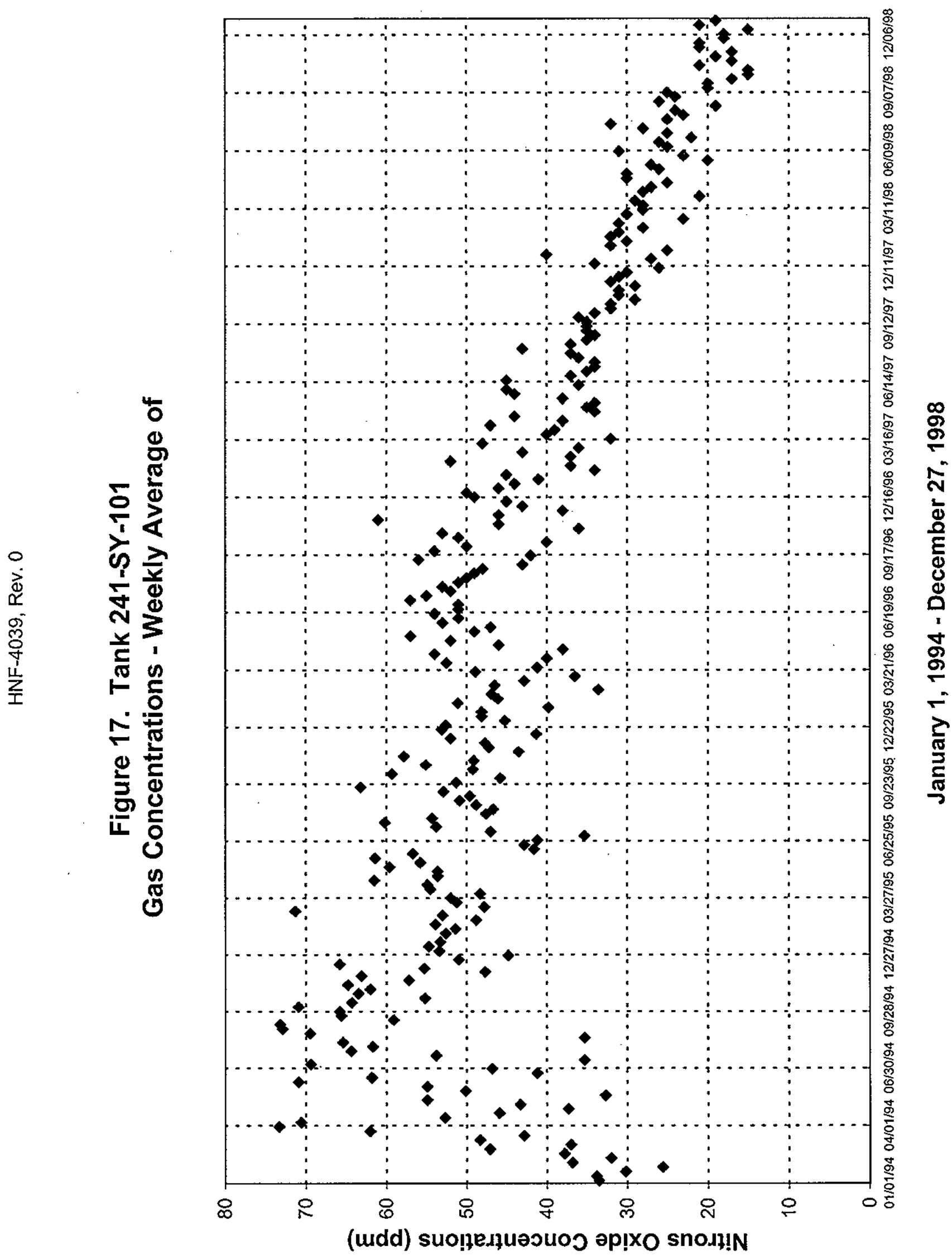

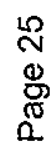




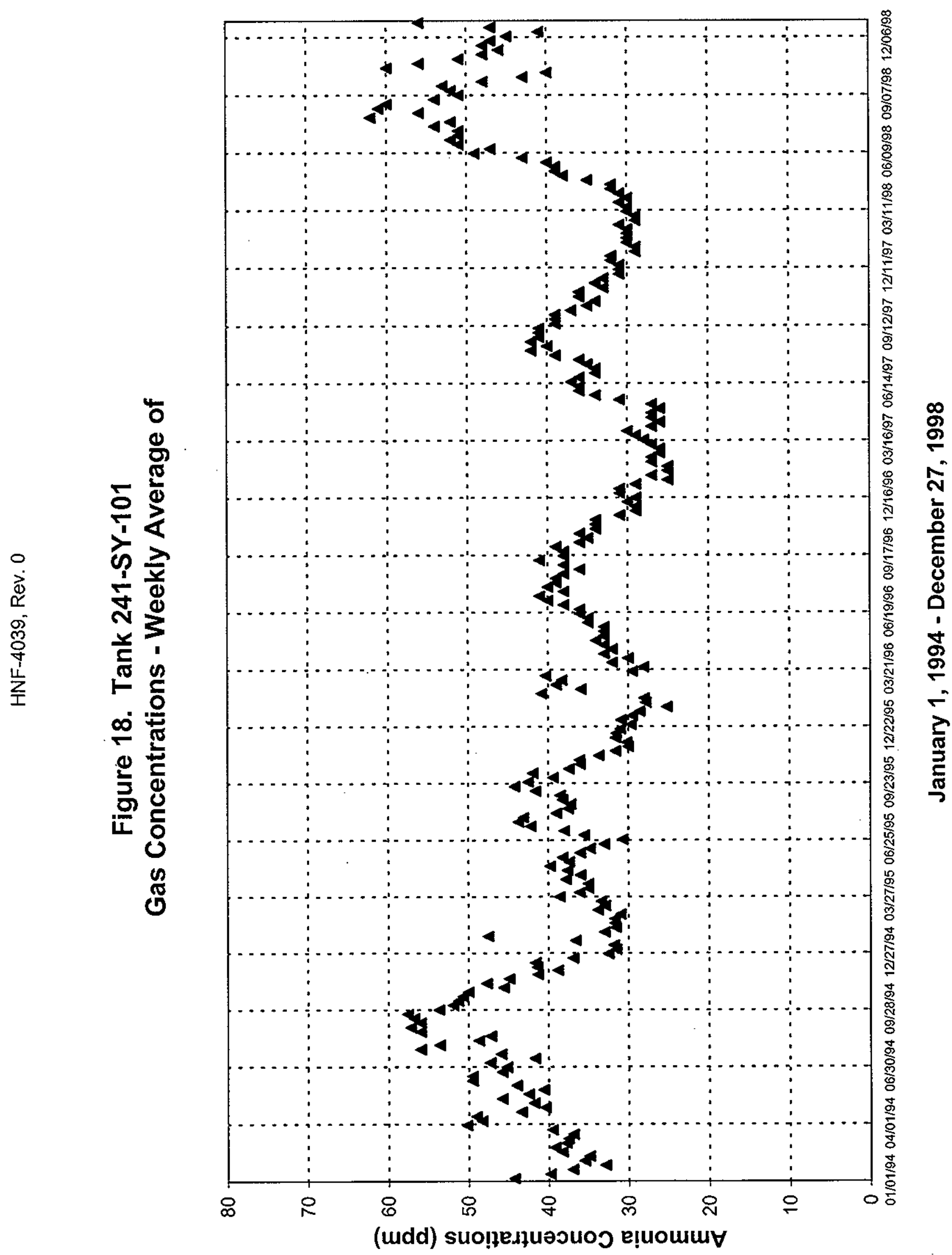




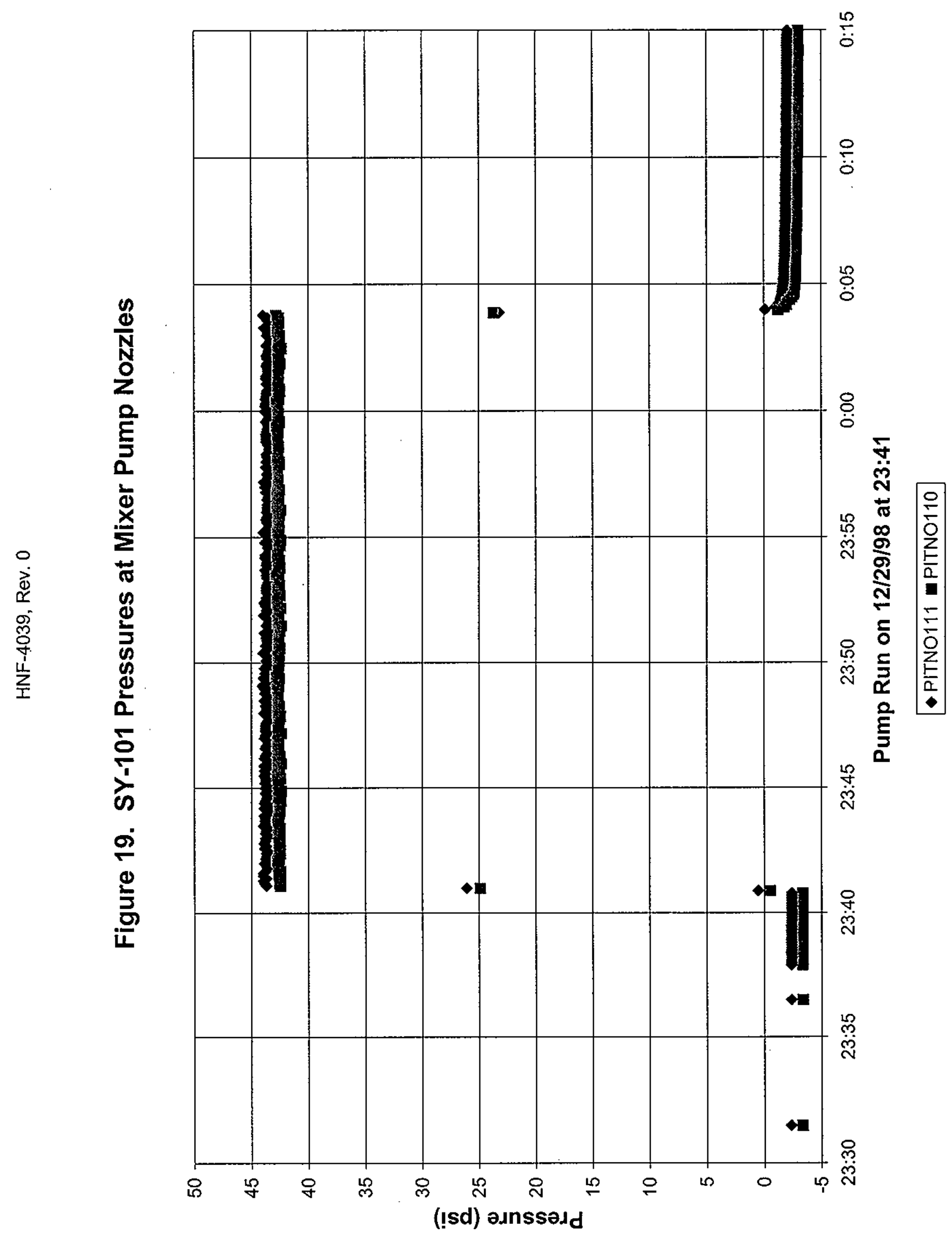




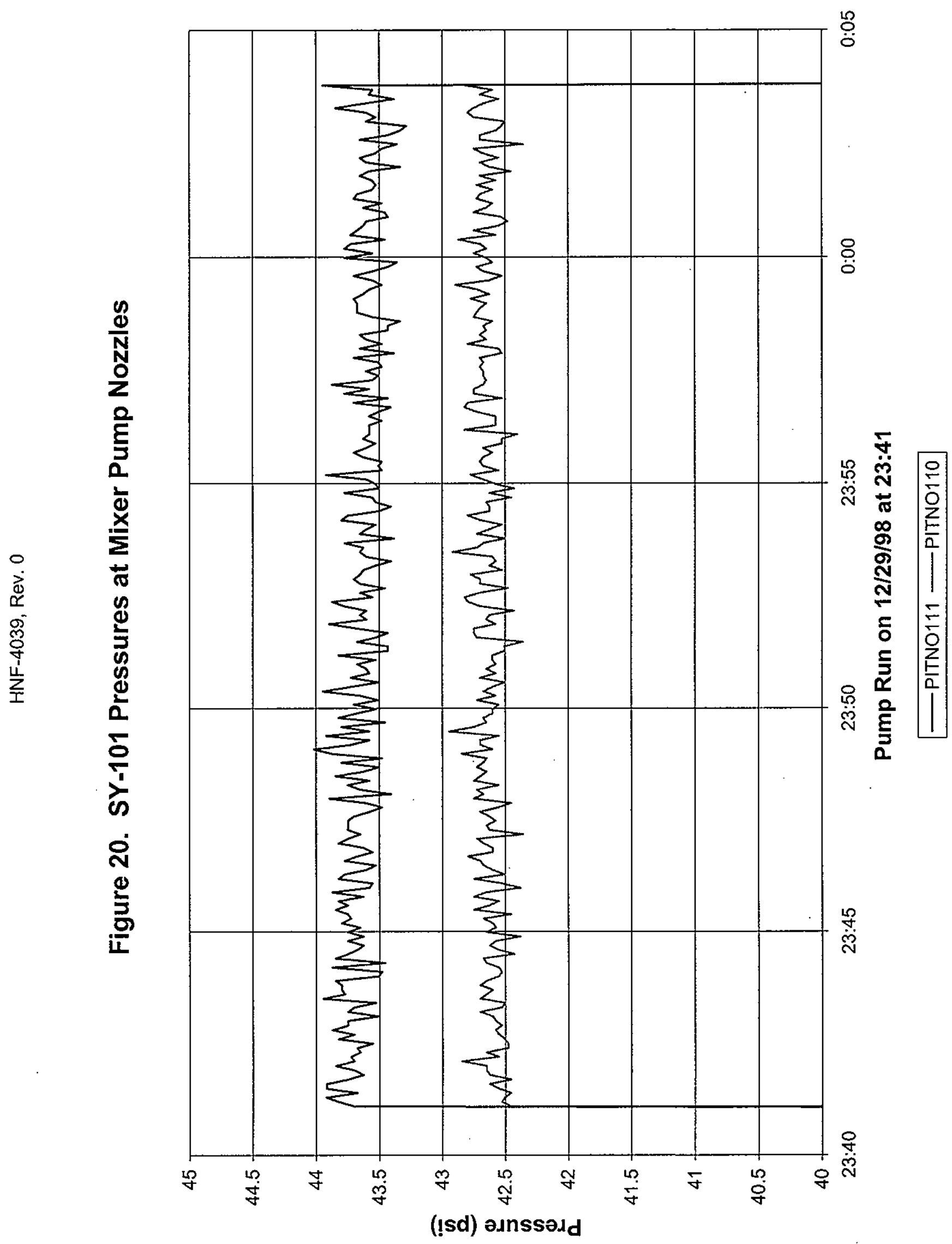

$\stackrel{\infty}{N}$
0
0
0
0 


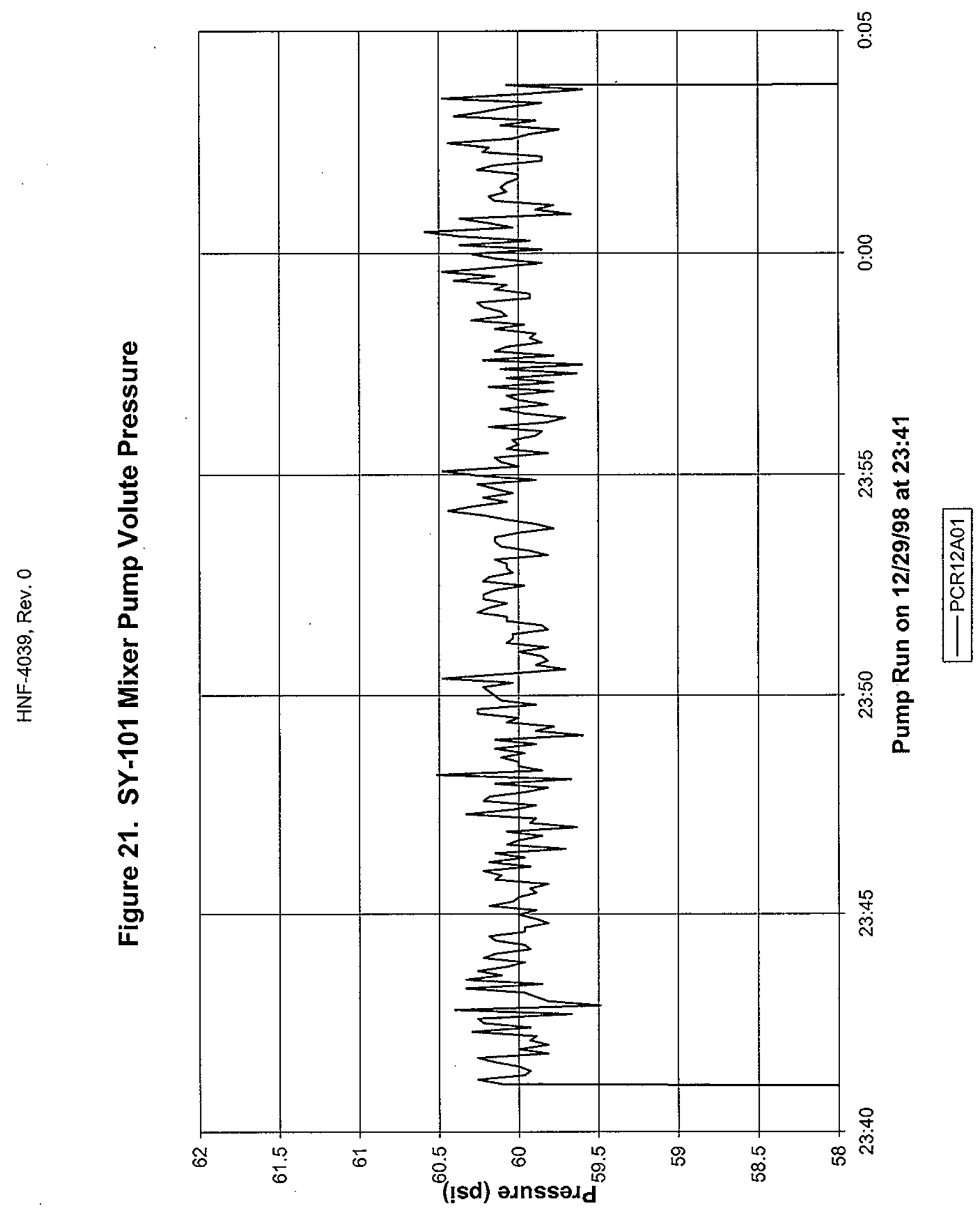

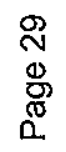




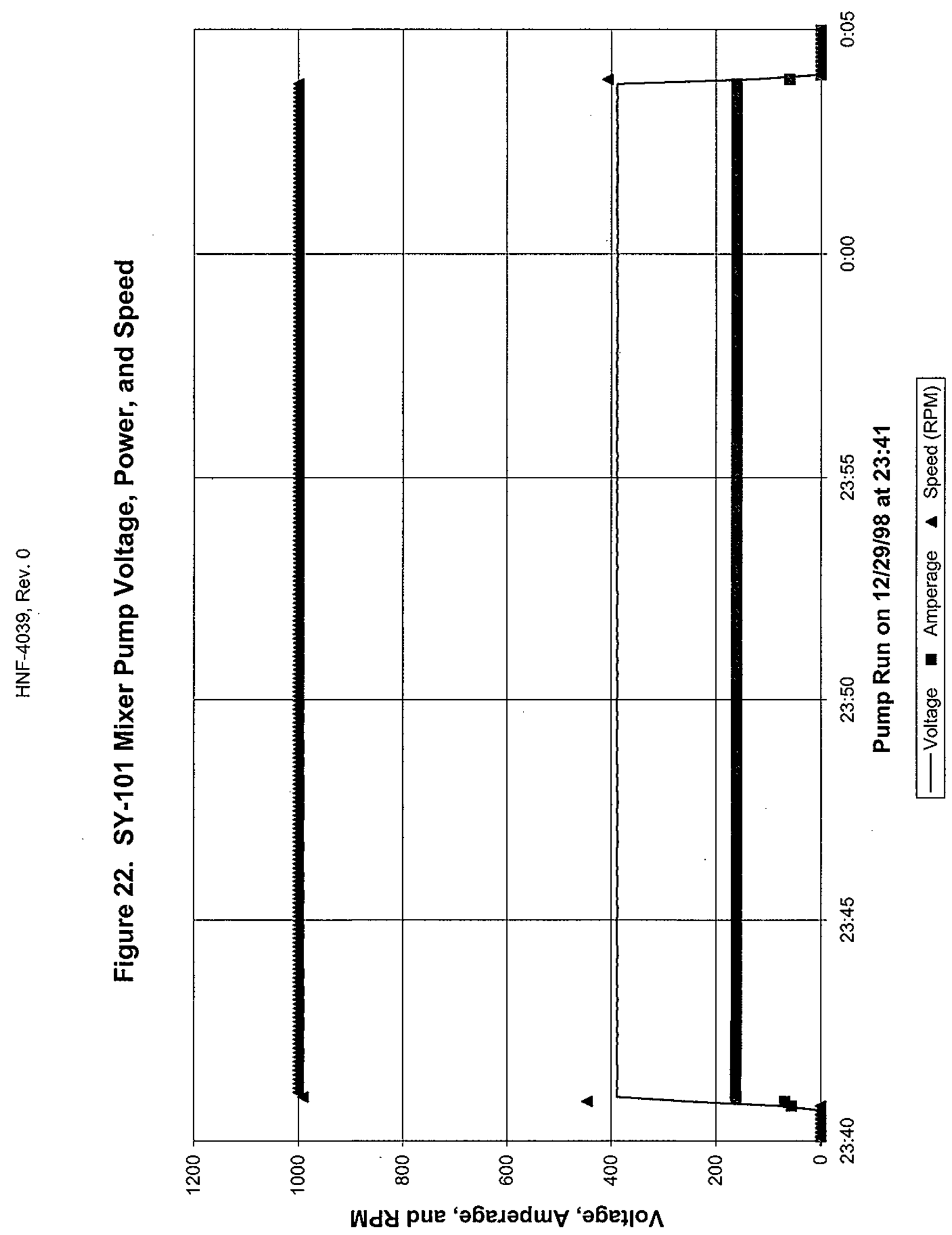




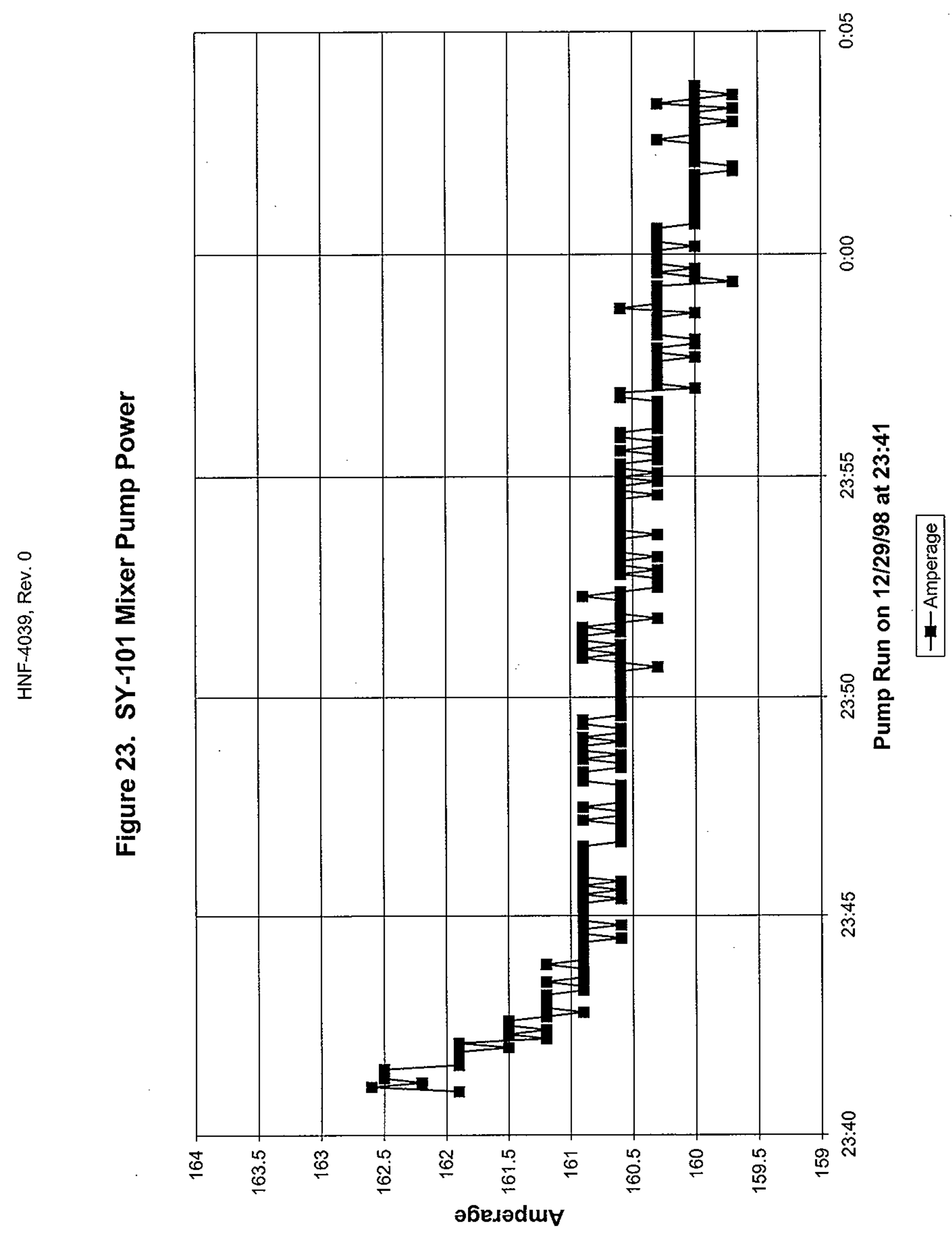




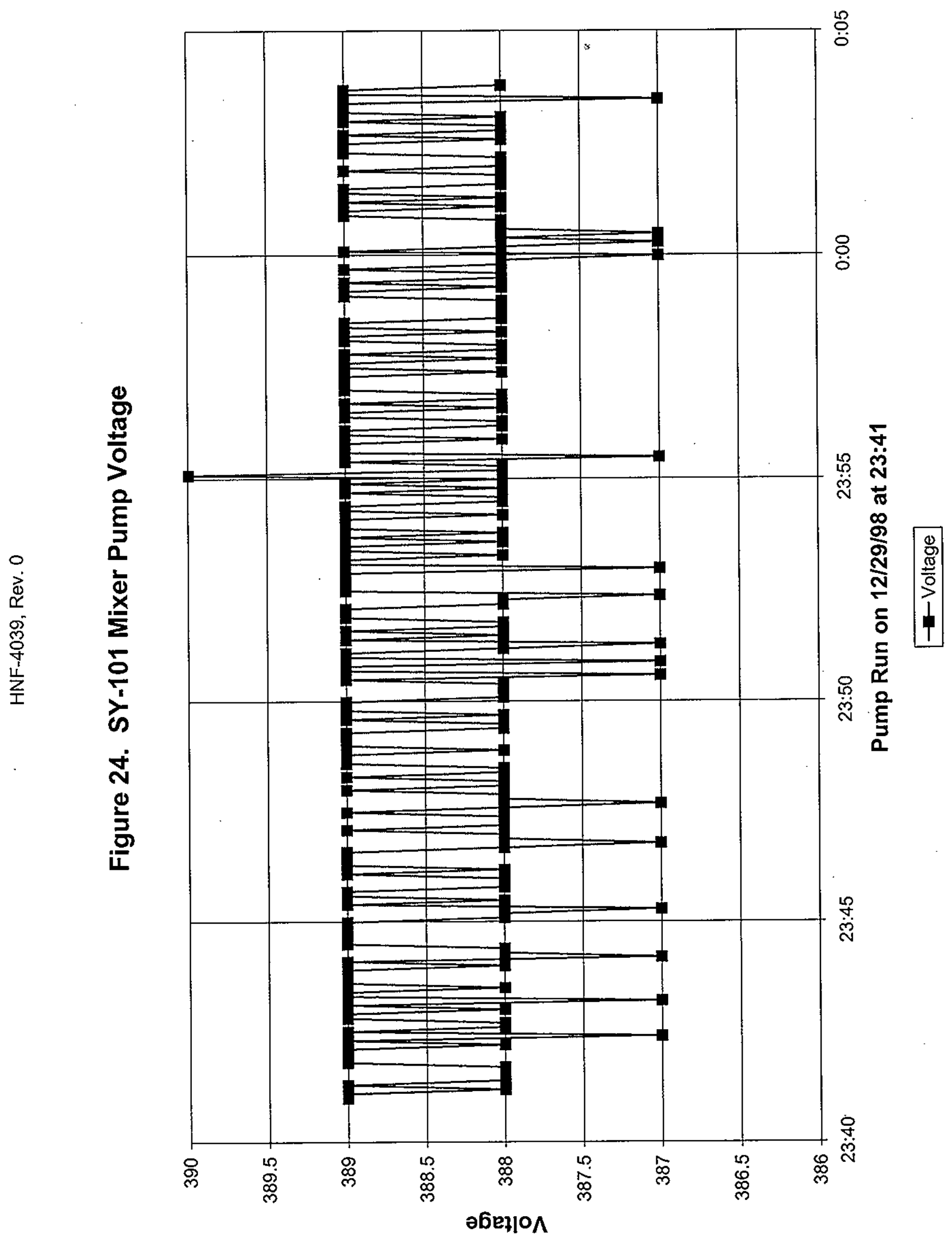

్
0
0
$\mathbb{1}$
0 


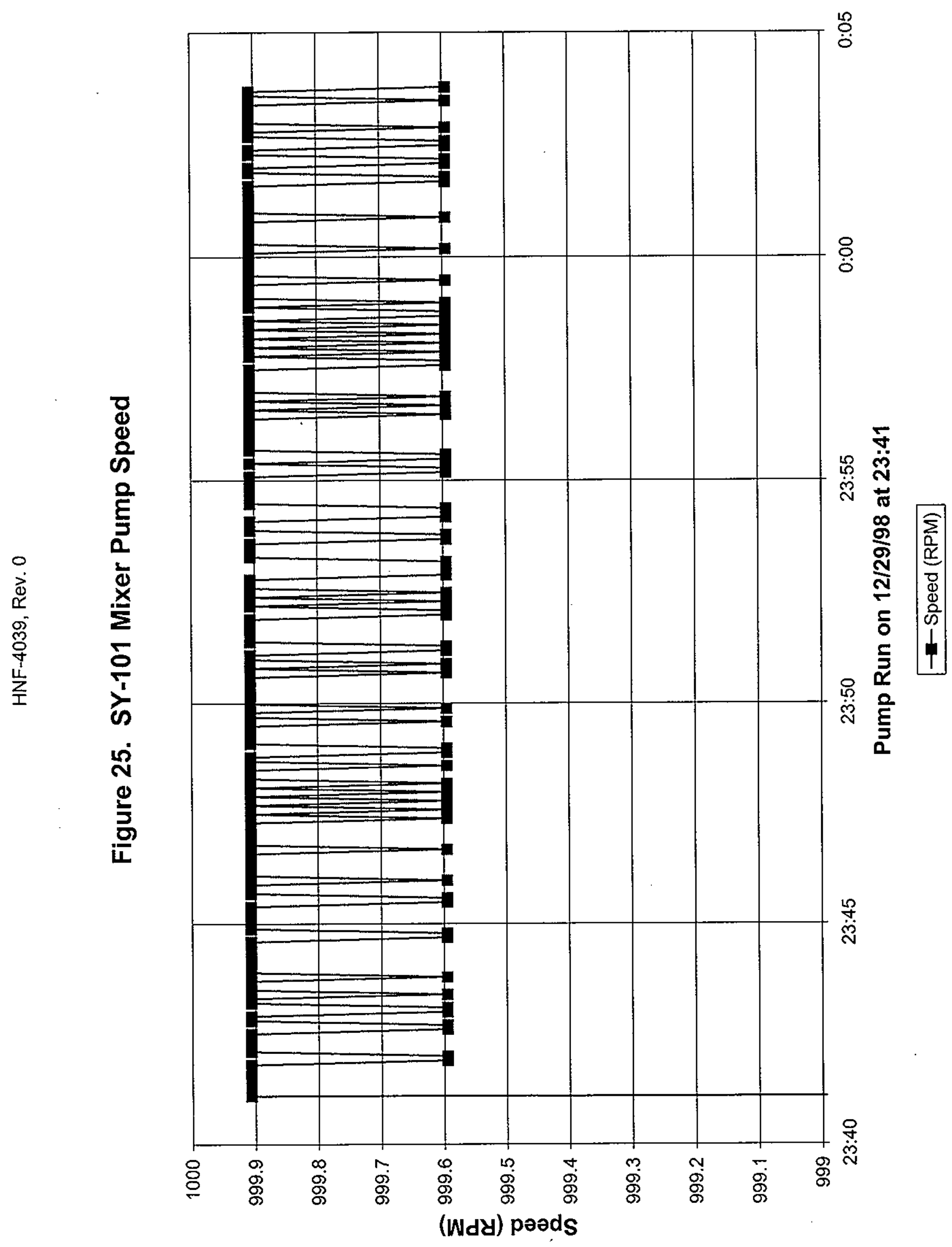




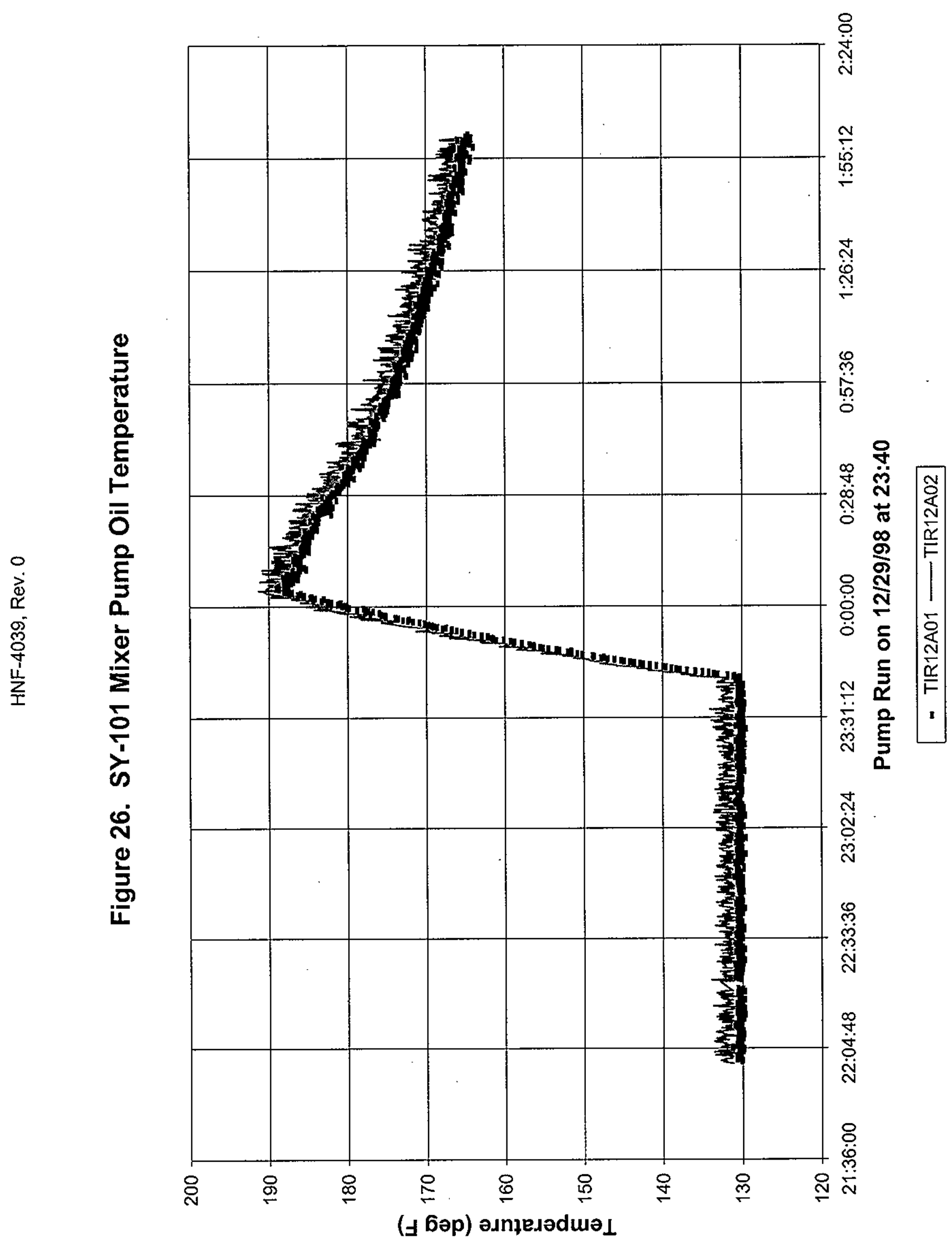

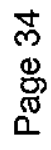




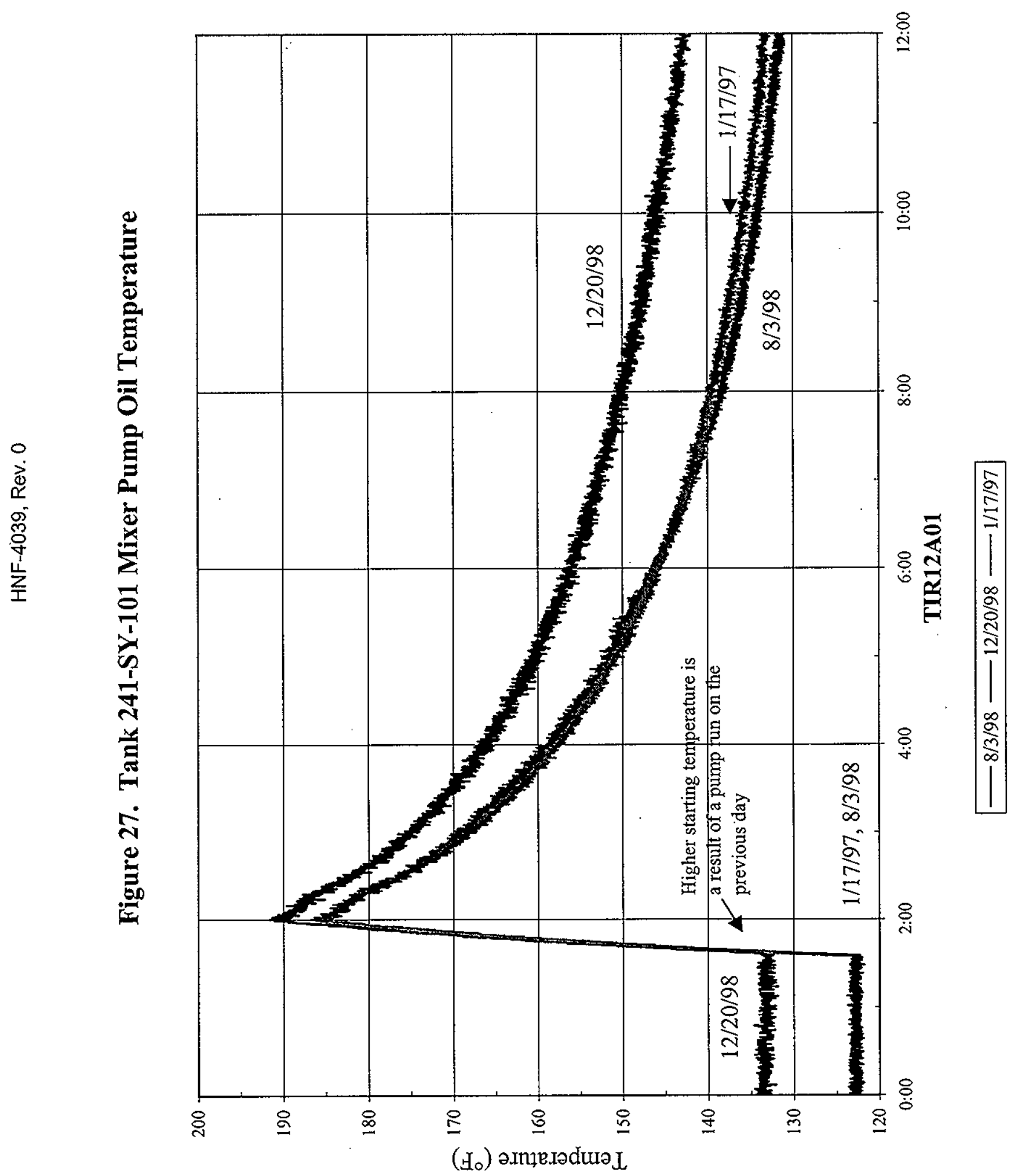




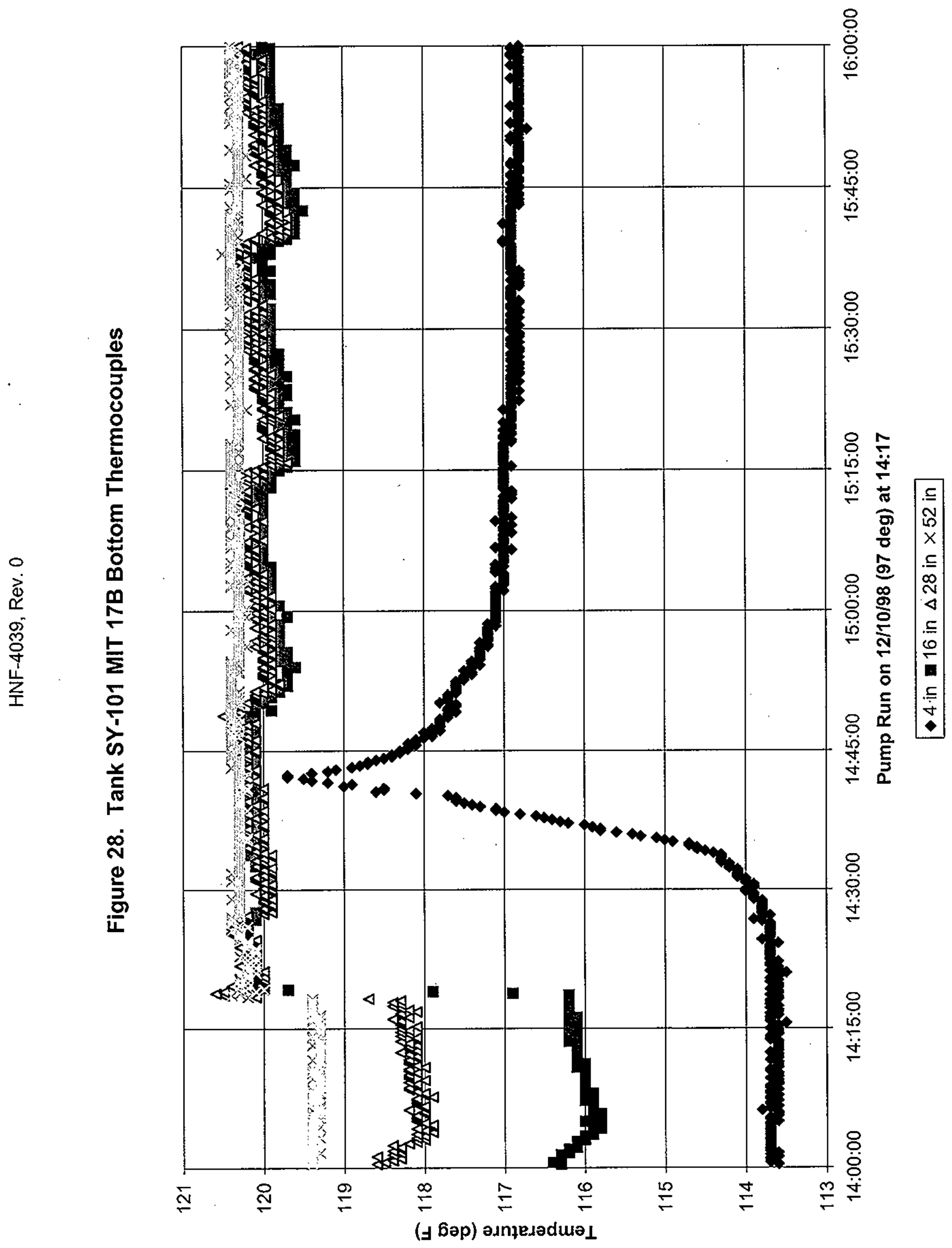

0
m
0
0
0 


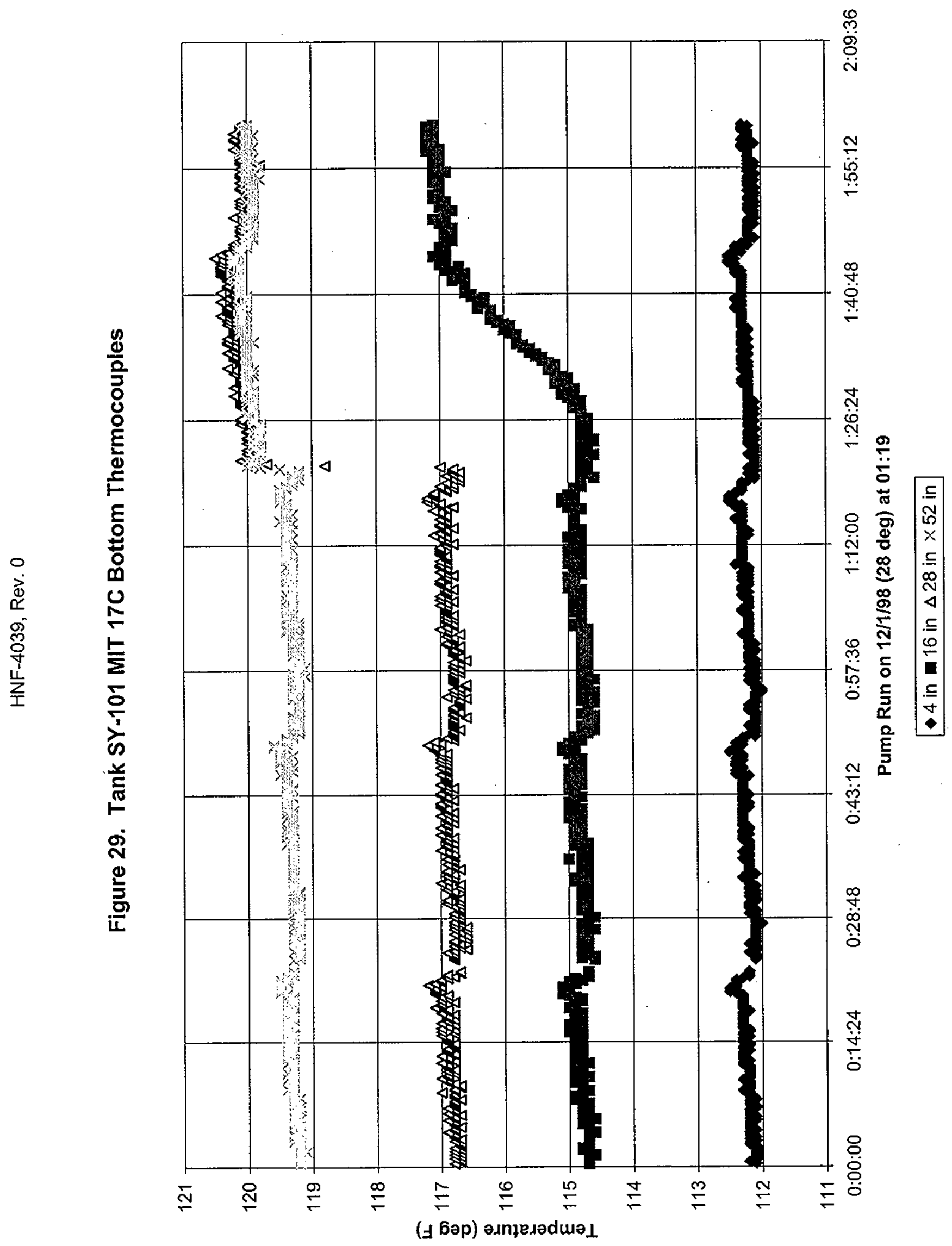

$\hat{m}$
$\mathbb{0}$
$\mathbb{0}$
0 


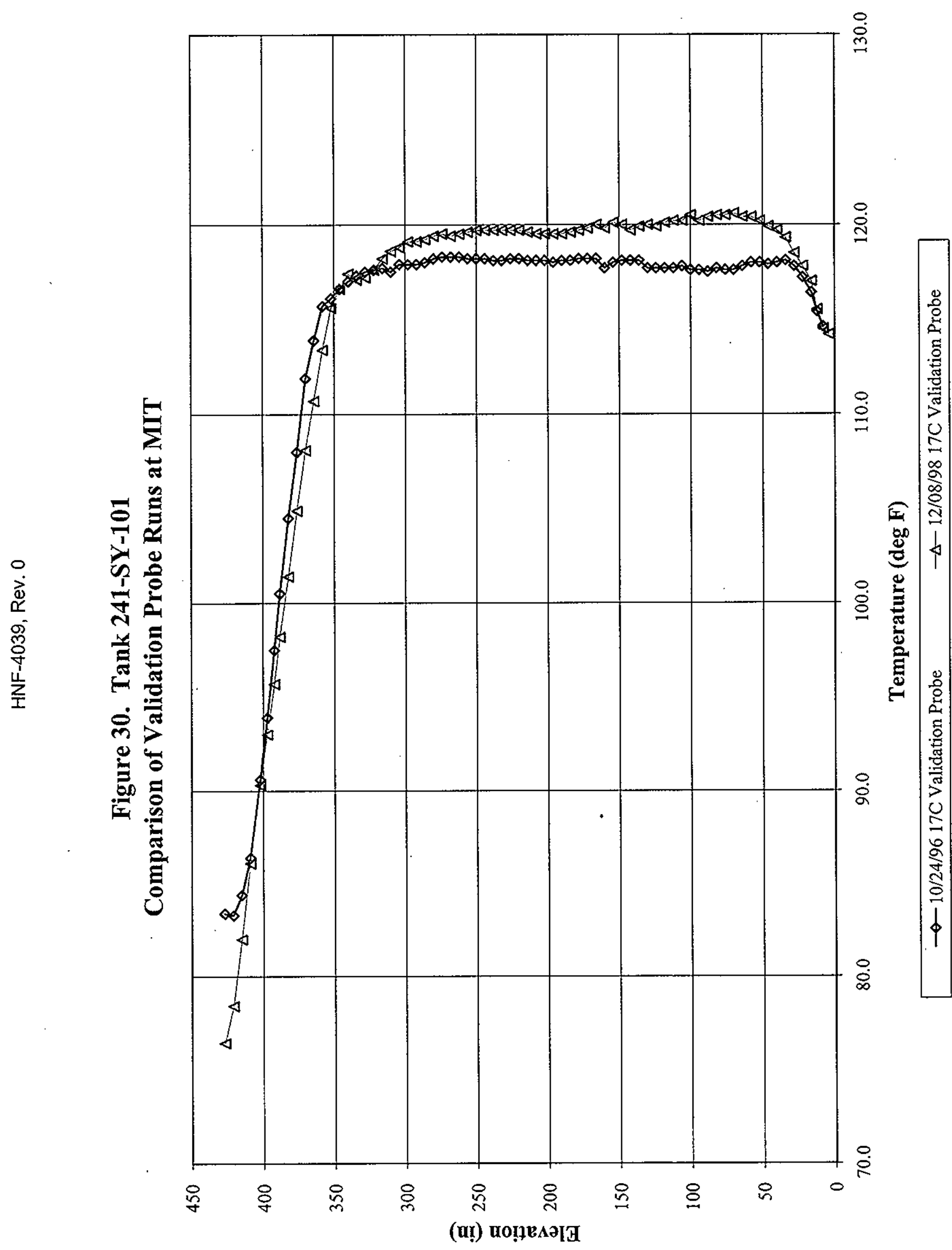




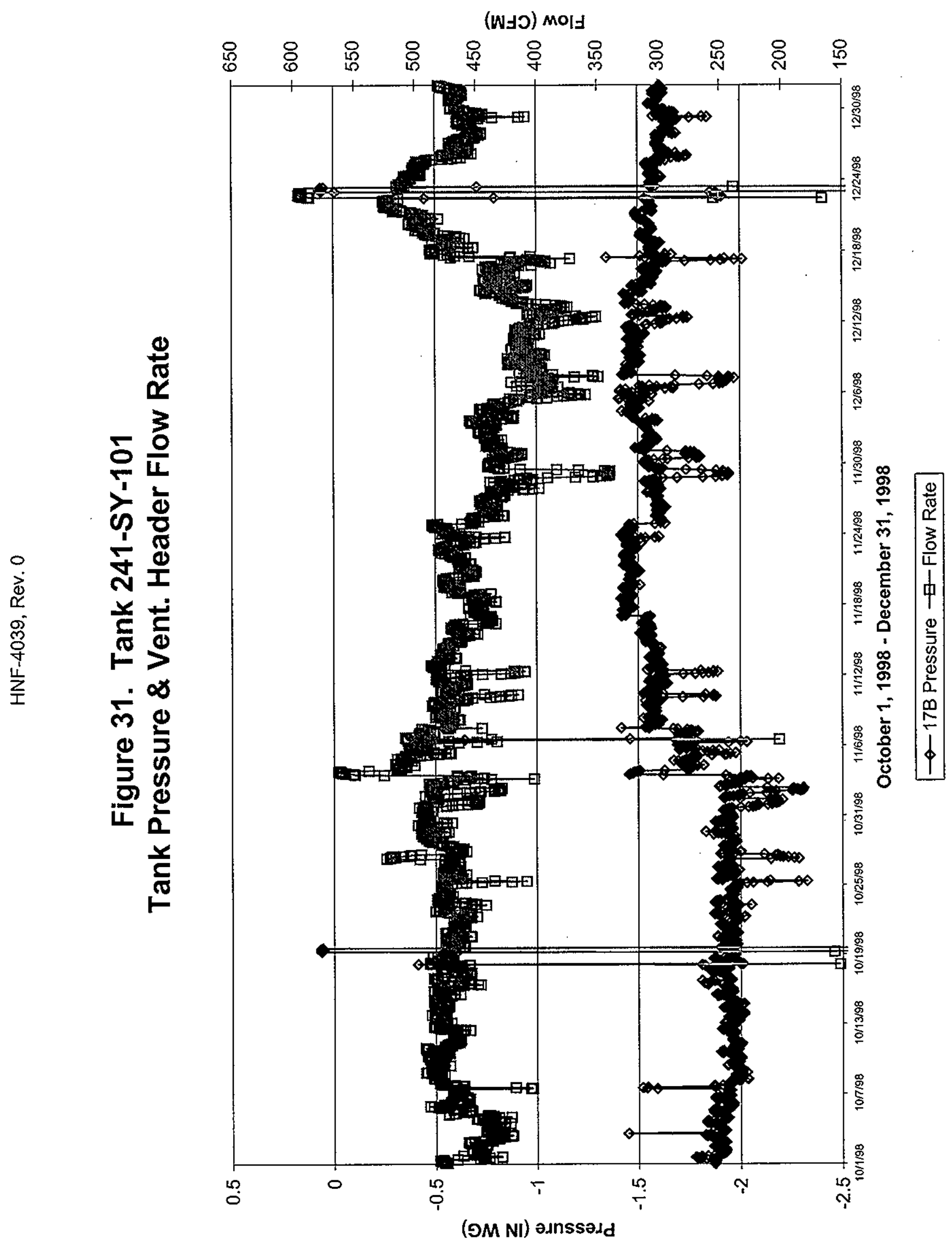

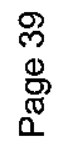




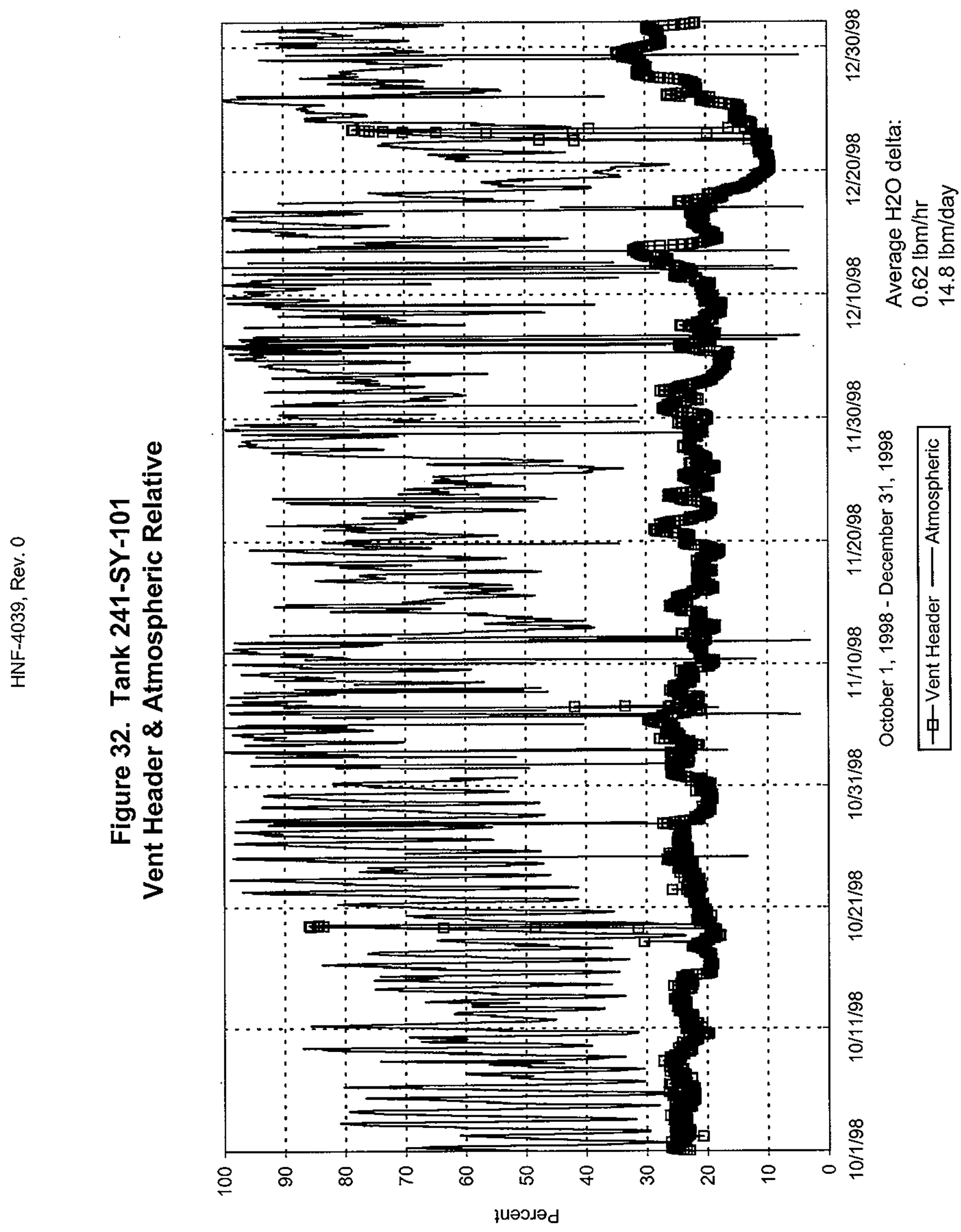

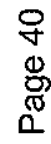




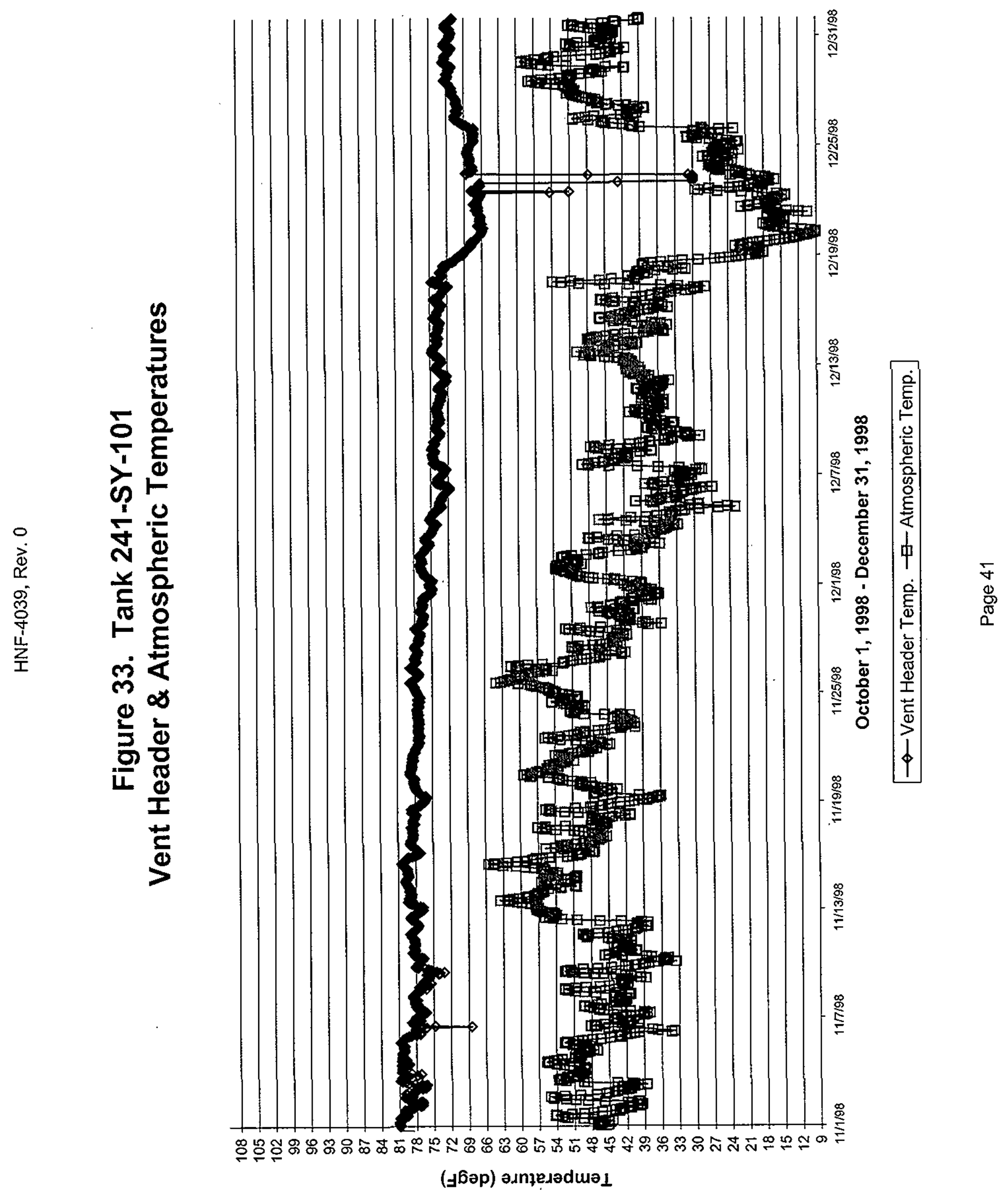




\section{DISTRIBUTION SHEET}

\begin{tabular}{|c|c|c|c|c|c|}
\hline \multirow{2}{*}{ Do $\quad$ Distribution } & \multirow{2}{*}{\multicolumn{3}{|c|}{ From }} & \multicolumn{2}{|l|}{ Page 1 of 1} \\
\hline & & & & \multicolumn{2}{|c|}{ Date $\quad 02 / 12 / 99$} \\
\hline \multicolumn{4}{|c|}{ Project Title/Work Order } & \multicolumn{2}{|c|}{ EDT No. EDT-611451 } \\
\hline \multicolumn{4}{|c|}{$\begin{array}{l}\text { HNF-4039, Rev. 0, "Quarterly Review of 241-SY-101 Mixer Pump } \\
\text { Data: October - December, 1998" }\end{array}$} & \multicolumn{2}{|c|}{ ECN No. N/A } \\
\hline Name & MSIN & $\begin{array}{c}\text { Text } \\
\text { With } \\
\text { Al] } \\
\text { Attach. }\end{array}$ & Text Only & $\begin{array}{l}\text { Attach./ } \\
\text { Appendix } \\
\text { Only }\end{array}$ & $\begin{array}{l}\text { EOT/ECN } \\
\text { Onty }\end{array}$ \\
\hline
\end{tabular}

COGEMA

T. R. Benegas

C. P. Shaw

DE\&S Hanford, Inc.

R. E. Bauer

R. J. Cash

G. D. Johnson

U. S. Department of Energy -

Richland Field office

C. A. Groendyke

R. G. Harwood

DOE/RL Reading Room

Fluor Daniel Hanford

S. L. Bauer

Lockheed Martin Hanford Corp.

M. J. Bailey

W. B. Barton

W. G. Brown

J. M. Conner

C. DeFigh-Price

G. J. Gauck

K. M. Ha11

R. A. Huckfeldt

N. W. Kirch

P. F. Kison

G. M. Koreski

L. S. Krogsrud

D. C. Larsen

J. A. Lechelt

R. R. True

R. P. Tucker

T.C.S.R.C.

Lockheed Martin Services. Inc.

Central Files

Pacific Northwest National Laboratory

F. E. Panisko

C. W. Stewart
R3-73

R3-74

$57-73$

S7 -73

S7- 73

$x$
$x$

$S 7 \div 54$

S7-54

H2-53

A3-02 $X$

T4-07

R2-12

T4 -07

R2-12

R2-12

T4-07

R2-12

R3-01

R2-11

R3-73

R2-11

T4-07

T4-08

R2-11

T4-07

T4-07

R1-10

$X$
$X$
$X$

$X$
$X$
$X$

B1-07

X

K8-34

K7-15

$x$
$x$
$x$
4
$x$
$x$
$x$
$x$
$x$
$x$
$x$
$x$
$x$
$x$
$x$
$x$
$x$

X

$x$
$x$
$x$
$x$
$x$
$x$
$x$
$x$
$x$
$x$
$x$
$x$
$x$
$x$

$x$
$x$
$x$
$x$
$x$
$x$
$x$
$x$
$x$

